\title{
Geochemistry of Precambrian basic igneous rocks between St. Jonsfjorden and Isfjorden, central western Spitsbergen, Svalbard
}

\author{
YOSHIHIDE OHTA
}

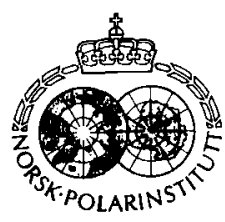

\begin{abstract}
Ohta, Y. 1985: Geochemistry of Precambrian basic igneous rocks between St. Jonsfjorden and Isfjorden, central western Spitsbergen, Svalbard. Polar Research 3 n.s., 49-67.

Two types of basic igneous rocks have been mapped in the middle Hecla Hoek succession in the area between St. Jonsfjorden and Isfjorden, central western Spitsbergen: the metadiabase-gabbros from the calc-argillo-volcanic formation and the Trollheimen volcanics from the quartzite-shale formation; both formations are older than the Eocambrian tilloid formation. The former has diabasic and gabbroic textures and occurs as thin discontinuous lensoid masses, while the latter exhibits definite extrusive structures with large amounts of pyroclastics and tuffs and relatively small amounts of solid lavas with abundant amygdules. Both basic rocks have been metamorphosed under the greenschist facies conditions, characterized by actinolite-epidote-biotite-albite assemblage.

The metadiabase-gabbros are moderate-high Fe tholeiites and the Trollheimen volcanics are mainly $\mathrm{Na}$-alkaline, accompanied by a small amount of calk alkaline rocks. The immobile minor and trace element contents indicate that the metadiabase-gabbros are oceanic, similar to the MORB, while those of the Trollheimen volcanics show non-oceanic chemical characteristics and occur in shallow marine, shelfshelfedge sediments.

The calc-argillo-volcanic formation reveals a shallow marine sedimentary environment and this does not conform with the oceanic nature of the metadiabase-gabbros, occurring in the formation. To overcome this disagreement, an idea of changing tectonic position is postulated to bring a shallow marine sedimentary regime onto a mid-oceanic tectonic zone. This hypothesis supports the concept of active consuming margin tectonics of the Svalbard Caledonides and explains, for example, the occurrence of the high-P metamorphic rocks in the western part of the present area.
\end{abstract}

Yoshihide Ohta, Norwegian Polar Research Institute, Rolfstangveien 12, 1330 Oslo Lufthavn, Norway; June 1984 (revised October 1984).

\section{Introduction}

Owing to strong overprinting of the Tertiary diastrophisms along the western coast of Spitsbergen, the Precambrian geology of the area still possesses many controversial problems. Different researchers (Harland et al. 1979; Hjelle et al. 1979; Krasilscikov 1979) have been unable to agree on the position of even major stratigraphic units, except for fossiliferous Lower Paleozoic and Eocambrian tilloid successions. The present study attempts to define chemical characteristics of the basic igneous rocks from two stratigraphic units of the Middle Hecla Hoek succession, late Riphean in age, distributed between St. Jonsfjorden and Isfjorden.

On the northern coasts of both St. Jonsfjorden and Isfjorden metadiabases and metagabbros from the calc-argillo-volcanic formation, the CAV formation hereafter (the Alkhornet formation of Harland et al. 1979), have been described by Hjelle et al. (1979) and four bulk rock analyses have been presented by Ohta (1979). An amygdaloidal basalt has been reported by Harland et al. (1979) in Gunnar Knudsenfjella from the Løvliebreen Formation (the quartziteshale formation of Hjelle et al. 1979, the Q-Sh formation hereafter). Further occurrences of basic rocks were described by Hjelle et al. (1979) in the area between St. Jonsfjorden and Isfjorden, but they were misinterpreted to be of the CAV formation. The observations up to that time were limited to coastal areas, but now the mapping has been extended into the inland nunatak areas between the two fjords (Fig. 1).

A N-S trending zone along the western coast of central Spitsbergen, bounded by the Forlandsundet Graben in the west and the Eastern Boundary Fault Zone in the east, is composed of the Upper (first three below) and Middle (latter two below) Hecla Hoek successions. From west to east: the Lower Palaeozoic flyschoids of the Bulltinden Formation, Eocambrian tilloid formation, possibly including the Jørgenfjellet For- 


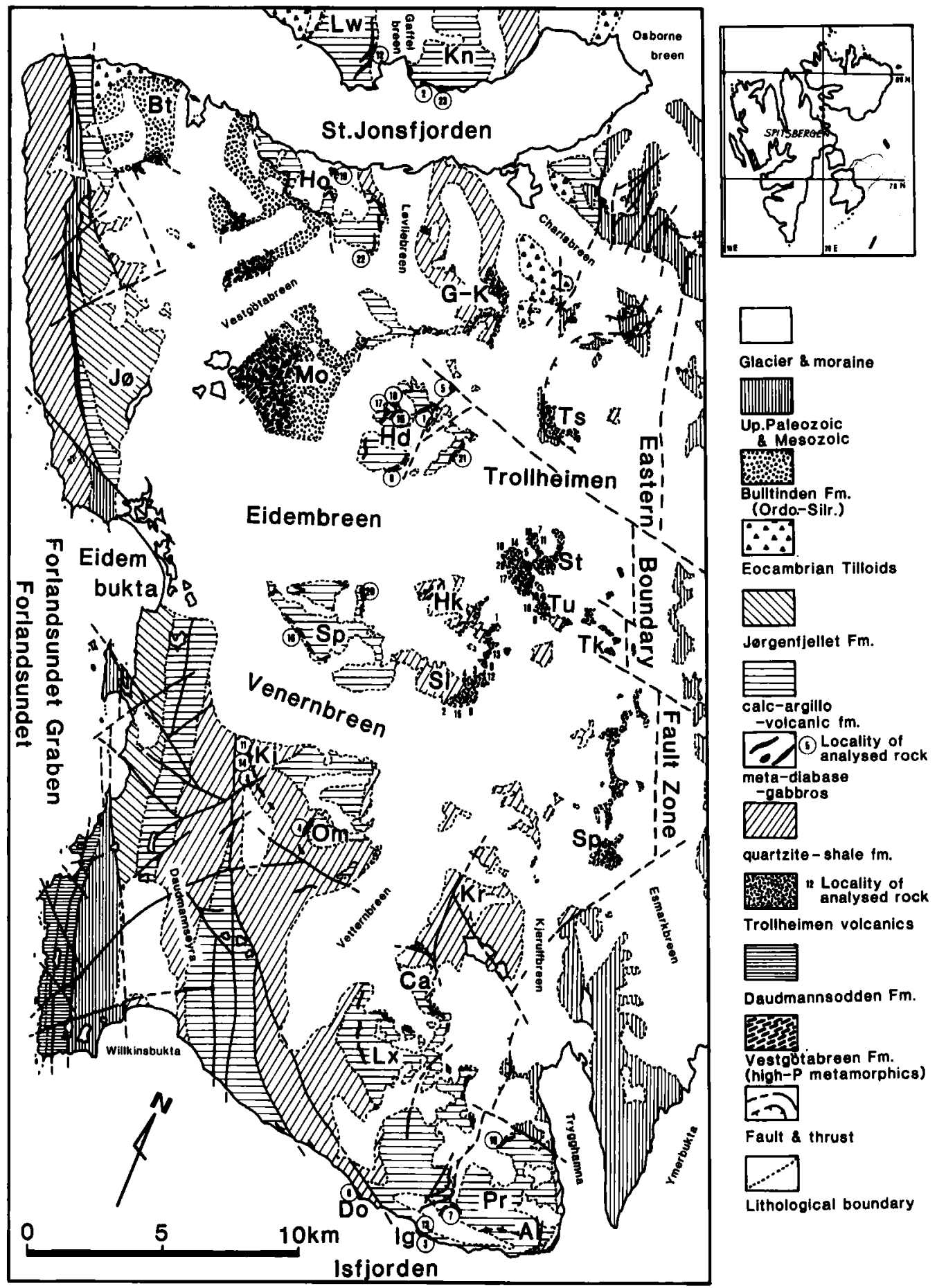

Fig. 1. Geological map of the area between St. Jonsfjorden and Isfjorden, central western Spitsbergen, with localities of the analysed rocks. Place names from $\mathrm{N}$ to $\mathrm{S}$ : $\mathrm{Kn}$ : Konowfjellet, Lw: Lowzowfjella, Bt: Bulltinden, Ho: Holmesletfjella, G-K: Gunnar-Knudsenfjella, Jø: Jørgenfjellet, Mo: Motalafjella, Hd: Huldrefjellet, Ts: Trollslottet, St: Stortrollet, Tu: Trollungen, Tk: Tussekallen, Hk: Heksefjell, Sl: Stallofjellet, Sr: Sparrefjellet, Ki: Kinnefjellet, Om: Ommafjellet, Sp: Spiret, Kr: Krokfjellet, Ca: Cappelenhøgda, Lx: Lexfjellet, Pr: Protektorfjellet, Do: Donpynten, In: Ingertreodden, Al: Alkhornet. 
mation, the CAV formation and the Q-Sh formation, in descending order. Besides these there is a high-P metamorphic complex, the Vestgötabreen Formation, in the western part (Horsfield 1972; Manby 1978; Ohta 1979). All formations have generally W-dipping structures, some are separated by thrust faults, and some overturned folds with W-dipping axial planes have been mapped (Hjelle et al. 1979; Ohta et al. 1984).

The CAV formation lies structurally on the Q-Sh formation. The contact between these two formations have been observed in several places. Two distinct platy limestone beds, one grey and the other yellow in colour and each 5-10 m thick, occur near the base of the CAV formation all the way from the southern coast of St. Jonsfjorden in the north to Protektorfjellet in the south. A brecciated quartzite has been observed at the contact on the ridge between Stallofjellet and Sparrefjellet, but the limestones mentioned above occur just above the contact. The folds of the quartzite beds in the Q-Sh formation are often very irregular, changing axial direction within a small area, while those of the limestone beds in the CAV formation have relatively steady trends. This difference sometimes gives an impression that these two formations had experienced different deformation histories, but this can be explained by differences of competence of the constituent beds. In general, the observations seem to confirm a sedimentary contact between these two formations, and the CAV formation is considered to be younger than the Q-Sh formation. Both formations are older than the Eocambrian tilloid formation, since the latter contains limestone boulders of the CAV formation.

\section{Occurrences of the igneous rocks}

The basic rocks studied are from the CAV and the Q-Sh formations and will be called the metadiabase-gabbros and the Trollheimen volcanics, respectively.

\section{Metadiabase-gabbros}

These rocks occur mainly as lenses up to $25 \mathrm{~m}$ thick, in black calcareous shale and impure limestone beds of the CAV formation. The surrounding beds are conformably folded around the lenses and almost no reaction between the basic rocks and surrounding rocks has been observed, except for a small tremolite skarn on the northern side of St. Jonsfjorden. The margins of the basic lenses are always schistose in texture, while the central parts have retained massive igneous texture in hand specimens, although most primary minerals have been recrystallised into new assemblages of the greenschist facies.

The basic rock lenses occur near the base of a thick limestone member in the lower part of the formation, but they are slightly oblique to the stratigraphic horizon, viz. $20-30 \mathrm{~m}$ above the base of the lower limestone member in the south of Protektorfjellet, more than $50 \mathrm{~m}$ above on the northern and western slopes of Lexfjellet, 30$150 \mathrm{~m}$ below the base of Ommafjellet and Kinnefjellet, two or more horizons $50-100 \mathrm{~m}$ above the base in Sparrefjellet and Huldrefjellet, and $30-50 \mathrm{~m}$ above the base in eastern Holmesletfjellet, and also in the upper part of the formation on the northern coast of St. Jonsfjorden. Two stock-like bodies $30-50 \mathrm{~m}$ across occur on the northern coast of St. Jonsfjorden in the middle of the lower limestone member. Possible intrusive occurrences have also been observed at Donpynten and Ingertreodden on the northern coast of Isfjorden.

\section{Trollheimen volcanics}

These rocks occur widely in the Trollheimen area in the Q-Sh formation (Fig. 1) and show clear eruptive structures, i.e., coarse pyroclastics, amygdaloidal cavities in lavas, possible pillow structures and green tuffaceous layers. They often possess layered structure representing these lithological varieties.

In the northernmost locality on Gunnar Knudsenfjella in the upper part of the Q-Sh formation pyroclastics are dominant while lavas are thin and infrequent. A $150 \mathrm{~m}$ thick pyroclastics + lava complex overlies the Carboniferous Culm sandstone separated by a gentle E-dipping fault in Trollslotten. The most extensive occurrence is in Stortrollet-Trollungen-Tussekallen, dominated by pyroclastics and lavas of more than $200 \mathrm{~m}$ thickness in the western branch. An anticline of $300 \mathrm{~m}$ wide sandstone-quartzite separates this from the eastern one which extends from Tussekallen to Spiret in the upper reach of Esmarkbreen, forming a distinct nunatak ridge along the west side of the Eastern Boundary Fault Zone. The eastern branch is mainly composed of dark 
coloured pyroclastics and lavas. The western branch extends to the southeastern part of Heksefjellet and eastern Stallofjellet, and may be continuous with the green phyllites of eastern Ommafjellet and Cappelenhøgda on both sides of Vetternbreen to the south. It is evident in Heksefjellet, Stallofjellet and Stortrollet that the volcanic rocks are intercalated by sandstone and quartzite beds of the Q-Sh formation. Several thinly laminated, fine-grained, grey-green coloured tuffaceous silt beds of limited lateral extension alternate with pyroclastics to form a steplike slope on the eastern site of Stallofjellet, and are considered to be deposits of a small closed and calm basin surrounded by volcanoes. Thus, the volcanics are definitely contemporaneous with the Q-Sh formation. Several dark grey limestone beds occur on the northeastern ridge of Gunnar Knudsenfjella below the pyroclastics and have well developed oolitic structures. Some interspace fillings of pyroclastic blocks have dark red-purple colours, suggesting subaerial weathering. The surrounding sediments indicate that the volcanics were deposited in a shallow marine, shelf environment, possibly with a continental crust below. The distribution of volcanic rock is restricted within the area of the Q-Sh formation and their thickness changes very rapidly. This may suggest that the volcanic rocks followed some deep faults which possibly occurred along a shelf edge.

\section{Petrography of the analysed rocks}

\section{Metadiabase-gabbros}

Diabasic and gabbroic textures have often been observed on the hand specimens from the central part of the lensoid bodies. Under the microscope, more than half of the 23 analysed rocks have retained clear igneous textures and primary minerals, although metamorphic recrystallization is intense in all of the samples. Nine rocks can be detected to be primarily pyroxene-bearing, mainly augitic, porphyrites ( Nos. 3, 5, 6, 7, 9, $12,13,15,22$ ), having up to $50 \%$ basaltic or trachytic groundmasses which are often difficult to recognize clearly. Six samples (Nos. 10, 16, 17, $18,20,21)$ show diabasic or doleritic textures, hardly preserved, and six others (Nos. 2, 8, 11, $14,19,23)$ are coarse-grained gabbros, three of them (Nos. 2, 8, 23) are pegmatitic. Two rocks
(Nos. 1, 4) are too schistose for estimation of original rock composition and texture.

The primary textures and minerals tend to be better preserved in the coarse-grained rocks and phenocrysts in the porphyritic rocks. Porphyritic rocks with a high proportion of groundmass and homogeneous medium-grained rocks, are more thoroughly recrystallized.

The mafic phenocrysts of the porphyritic rocks are mainly clinopyroxene. A few rocks have small amounts of orthopyroxene and basaltic hornblende, and locally form ophitic-subophitic and gabbroic textures with prismatic plagioclase. In the pegmatitic rocks very coarse-grained primary crystals up to $15 \mathrm{~mm}$ long have survived; two rocks (Nos. 2, 8) have reddish brown basaltic hornblende grains and three (Nos. 2, 8, 23) have large relict flakes of brown biotite. Opaque minerals, with a rim of dusty sphene aggregates, are large and have an angular outline inherited from primary igneous crystals in the coarse-grained rocks. Apatite has a strongly idiomorphic long prismatic shape.

The schistose rock (No. 1) from a marginal part of a lensoid body has totally lost its primary structure and has a large surplus of dolomite derived from the surrounding calcareous rocks.

\section{Trollheimen volcanics}

Pyroclastic rocks are dominant in most areas; black, violet and dark green block lavas, green tuffs and tuff-breccias. Lavas are thin, up to $15 \mathrm{~m}$ in thickness. Most rocks have various amounts of amygdules, often showing a layered structure. Interspaces of pyroclastic blocks are filled with dark sandy and green tuffaceous sediments. Probable pillow lava structure has been seen in the eastern part of Stallofjellet. The lavas are mostly black and some are violet, rarely free from amygdules, and are mostly dense, fine-grained rocks without any phenocrysts visible in the hand specimens, except for the P-group rocks (see later).

Widely spaced cleavages, marked by black shiny chlorite-rich surfaces, are locally developed, and elongation of the amygdules and pyroclastic blocks, the latter are a few $\mathrm{cm}$ across and some metres long, coincide with the regional b-lineation trend.

Two petrographic groups, porphyritic (the $\mathrm{P}$ group) and basaltic (the B-group), are recognized under the microscope.

The P-group rocks (Nos. 10, 17, 20) occur near 
a sheared zone in the middle part of Stortrollet as two narrow greenish layers. The rocks have dark spots of mafic grains including relict clinopyroxene. The spots occupy $20-50 \%$ of the rocks and primary pyroxene phenocrysts are strongly converted into actinolite; uralitized remnants also exist. The primary pyroxene certainly had zoned, and possibly corroded, structures. Plagioclase phenocrysts occur in very small amounts.

The very fine-grained, grano- and nematoblastic groundmasses comprise half to two-thirds of the rocks. Outline of mafic aggregates and small plagioclase laths are occasionally preserved and suggest primary basaltic texture. Opaque grains are often rimmed by granular aggregates of sphene and occur densely in the primary groundmass domains. No amygdules have been seen in these rocks.

The B-group rocks have many amygdules filled with coarse-grained calcite and are often rimmed by opaques. The outlines of the amygdules are often stretched into lenses in some rocks. Relatively large flakes of chlorite and biotite occur along calcite grain boundaries near the margins of the amygdules. Micro-phenocrysts of plagioclase laths are often locally preserved in these rocks. Some have oligoclase composition, while most are recrystallized into a very fine-grained granoblastic albite mosaic. Primary mafic constituents of the groundmasses have been totally converted into secondary phyllosilicate flakes and granular sphene-opaque aggregates.

Only one basaltic hornblende remnant, deep brown in colour and strongly actinolitized, has been seen in No. 6. Opaque minerals often show a platy shape which has originated as rims around plagioclase laths, and their arrangement represents a relict trachytic texture. The primary groundmass domains are characterized by large amounts of opaque grains.

\section{Metamorphism}

\section{Metadiabase-gabbros}

Strong schistosity is not present, except for Nos. 1 and 4, but granulation is distinct in all the rocks. Mafic phenocrysts are partly, in some cases totally, converted into actinolite along the margins and cracks, the plagioclase grains having been changed into albitic composition even when the primary crystal's outline has survived.
Groundmasses were recrystallised into smallgrained, granoblastic texture of albite and epidote, with nematoblastic actinolite in many rocks. Actinolite also shows idiomorphic shape and some examples are bluish-green $(\mathrm{Z}=$ pale green, $\mathrm{Y} \& \mathrm{X}=$ fresh blue-green), while that in No. 21 has a brownish-green tint $(=Y \& X)$ indicating an approach to hornblende. Chlorite occurs only in very small amounts, except for Nos. 1 and 22 , and is preserved inside mafic spots and in relict mafic phenocrysts. Pale brown coloured biotite flakes, not relict, occur in six rocks (Nos, 3, 5, $9,13,19,23)$. The hornblende phenocrysts of one pegmatitic rock (No. 23) have been totally converted into a dense mat of tiny greenish-brown biotite flakes, showing similar texture to vermiculite, and this rock has brown stilpnomelane as radial aggregates. Very small amounts of carbonates are present in all rocks, except for carbonate-rich No. 1.

A coarse-grained gabbro (No. 2) with bluegreen actinolite has marked amounts of serpentine. A strongly schistose rock (No. 1) is mainly composed of chlorite and dolomite, and the ACF projection of its bulk composition is close to the chlorite-dolomite tie line (Fig. 2a).

The metamorphic mineral assemblages show two grades: 1) chlorite-albite assemblage (Nos. 1 and 22) and 2) actinolite-epidote-(biotite)albite. The latter can be subdivided into two terms of textures: $2-1$ ) with large amount of relict primary minerals, and 2-2) with less or none (Nos. $4,10,15,16,17,18,20,21)$. Since 1 ) is only two rocks, it can safely be stated that the metamorphic grade of the metadiabase-gabbros is represented by 2) assemblage, and the difference between 2-1) and 2-2) is a matter of recrystallization kinetics, that the coarse-grained primary textures tending to prevent further reaction in these rocks.

\section{Trollheimen volcanics}

Half the analysed B-group rocks show weak cleavages marked by phyllosilicates and opaque seams and some have lost all primary textures. The plagioclase laths are mostly changed into albite composition, even when the outlines are preserved. Very small mosaic grains of albite, some micro-poikiloblastic, are the main constituents of the groundmasses. Chlorite forms clusters of lensoid shapes, partly showing gradational change into pale brown biotite and almost completely transformed in three rocks (Nos. 17, 18, 19) which 
have well developed actinolite and epidote. Granular epidote occurs in plagioclase in six rocks including all P-group rocks (Nos. 6, 10, 17, 18, 19,20 ), in most cases with nematoblastic actinolite. Sphene forms granular aggregates of irregular shape and also often rimes around opaque grains. Small amounts of hematite occur with mafic aggregates. Notable amounts of apatite were observed in three rocks (Nos. 10, 18, 19).

Three groups of metamorphic mineral assemblages are distinguished:

1) chl-alb-cc-sph-op-(ht): Nos. $5,7,11,12,13$, 15.

2) (chl)-bi-alb-cc-sph-op-(ht): Nos. 1, 2, 3, 4, 8, $9,14,16$.

3) act-ep-bi-(chl)-(cc)-sph-op-ht: Nos. 6, 18, 19, $10,17,20$.

None of the rocks in assemblage (3) have calcite amygdules, and they have only very small amounts of calcite locally in their groundmass. Thus, the occurrence of actinolite and epidote in these rocks was possibly caused by low $\mathrm{PCO}_{2}$. The rocks in assemblage (3) tend to have lower $\mathrm{CaO}$ than the others on the ACF diagram (Fig. 2b). All P-group rocks belong to this assemblage.

On the other hand, a prograde change from chlorite to biotite is clear between assemblages 1) and 2)/3).

Three rocks (Nos. 5, 14, 16) have some sericite and have lower F-contents than the others in Fig. 2b. The chlorite in these rocks has dark blue birefringence, while in the rest of the rocks it is dark brown, suggesting the chlorites are of different composition.

Some of the bulk composition plots on the ACF diagram (Fig. 2b) do not agree with the observed mineral assemblages; this is probably due to local equilibrium in small domains under low grade metamorphic condition.

\section{Petrochemistry, major elements}

\section{Metadiabase-gabbros}

Suspicious contamination of sedimentary materials into the rocks and the reliability for the consideration of primary chemistry are examined on two Niggli-value diagrams (Figs. 3a and b) (Simonen 1953; Leake 1963) and an alkali diagram (Fig. 3c) (Hughes 1973). Figs. 3a and b show that the pegmatitic rocks (Nos. 2, 8, 23) and a strongly schistose rock (No. 1) have extreme compositions, although, except for No. 1, no contamination was observed under the microscope. No. 8 has a texture where large clinopyroxene prisms support each other to form a coarse mosaic, and can thus be called a pyroxene pegmatite. Its diopside content is possibly responsible for the very high $\mathrm{CaO}$ content of the rock. No. 23 has large hornblendes totally replaced by green bio-
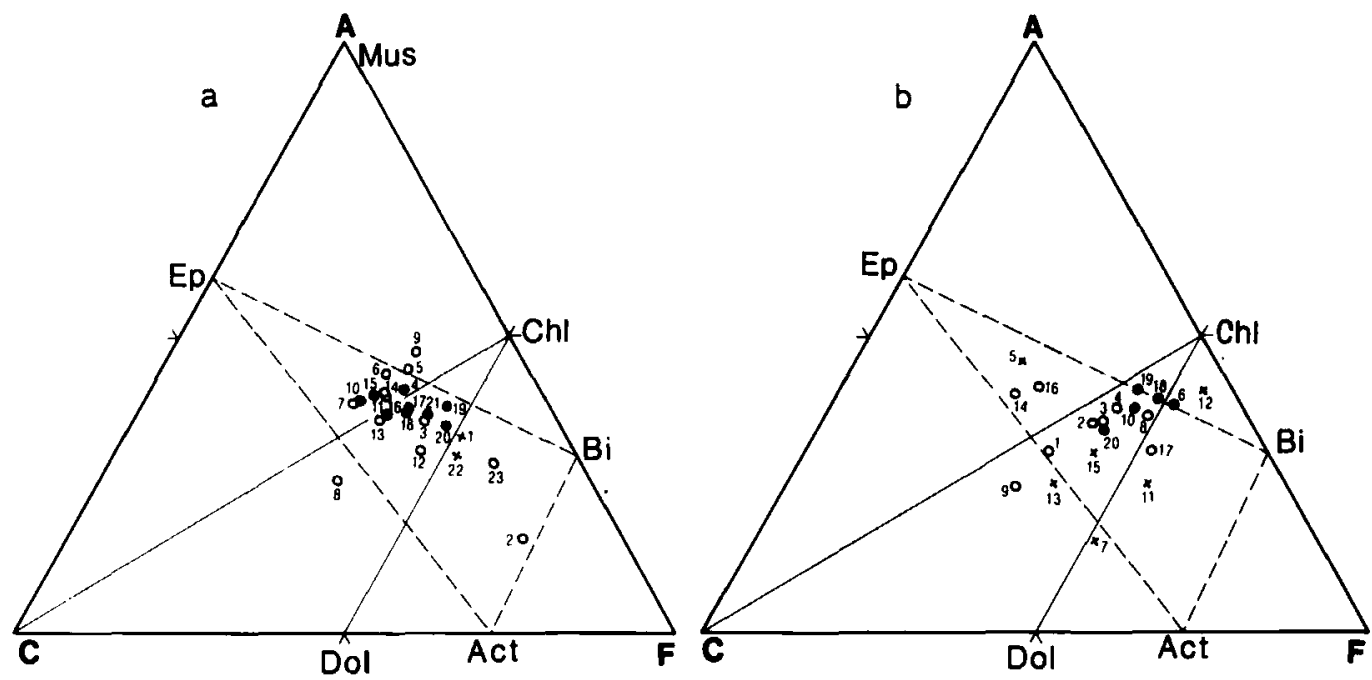

Fig. 2. ACF diagrams and the observed metamorphic mineral assemblages.

a. Metadiabase-gabbros. Observed assemblages. cross: chl-alb, open circle: act-ep-(bi)-alb with relatively large amount of relict minerals, dot: same as open circle, but less relict minerals.

b. Trollheimen volcanics. Cross: chl-alb-cc, open circle: chl-bi-alb, dot: act-ep-bi-alb. 

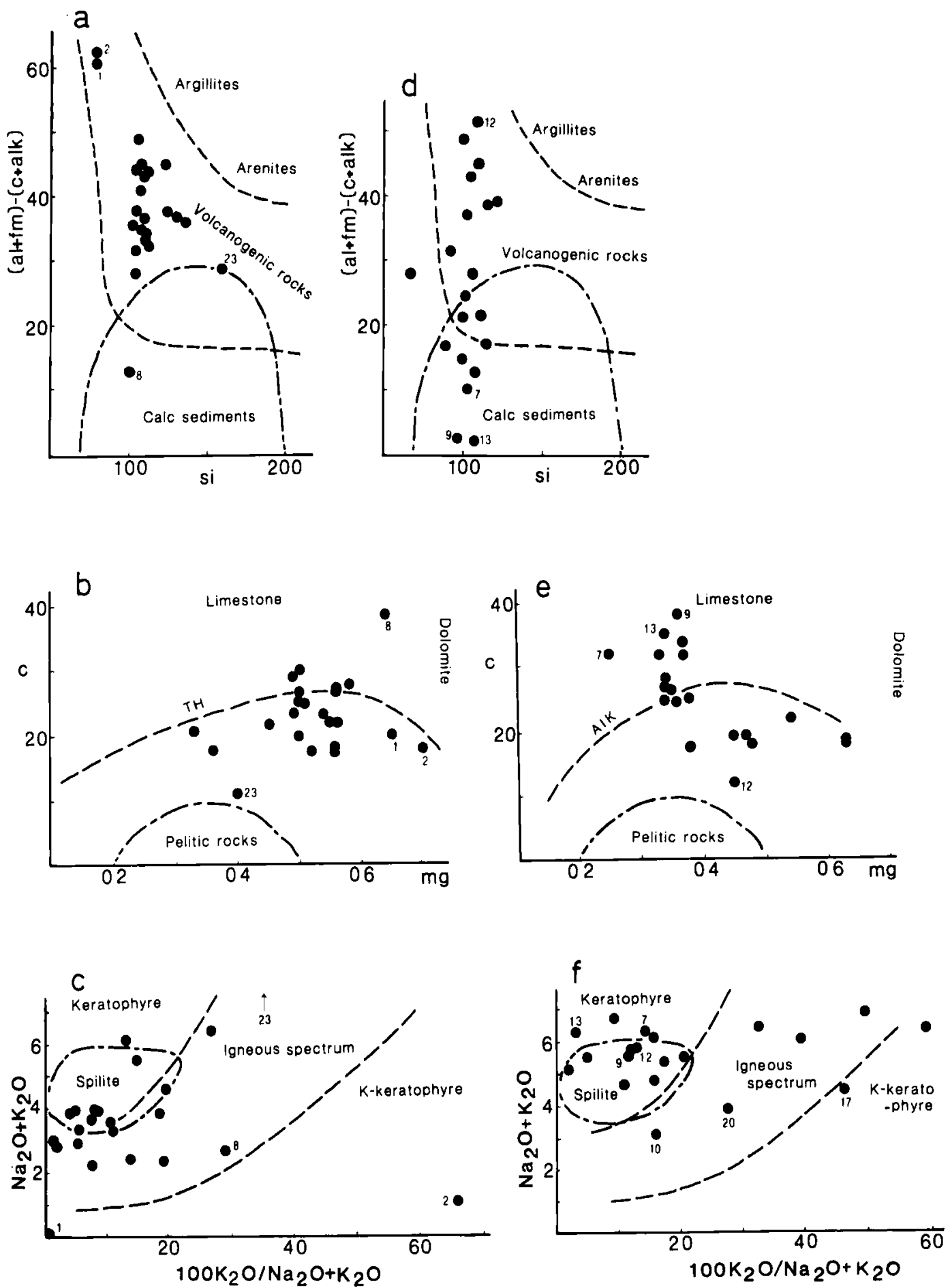

Fig. 3. Niggli-values and alkali diagrams. Metadiabase-gabbros: 3a, b and c, Trollheimen volcanics: $3 d$, e and f. a and d: after Simonen (1953) with some modifications. b and e: after Leake (1963), TH in 3-b: differentiation trend of Karroo dolerite, ALK in 3e; that of Na-alkalic rocks from Ethiopia (Mohr 1960). 3c and f: after Hughes (1973). 

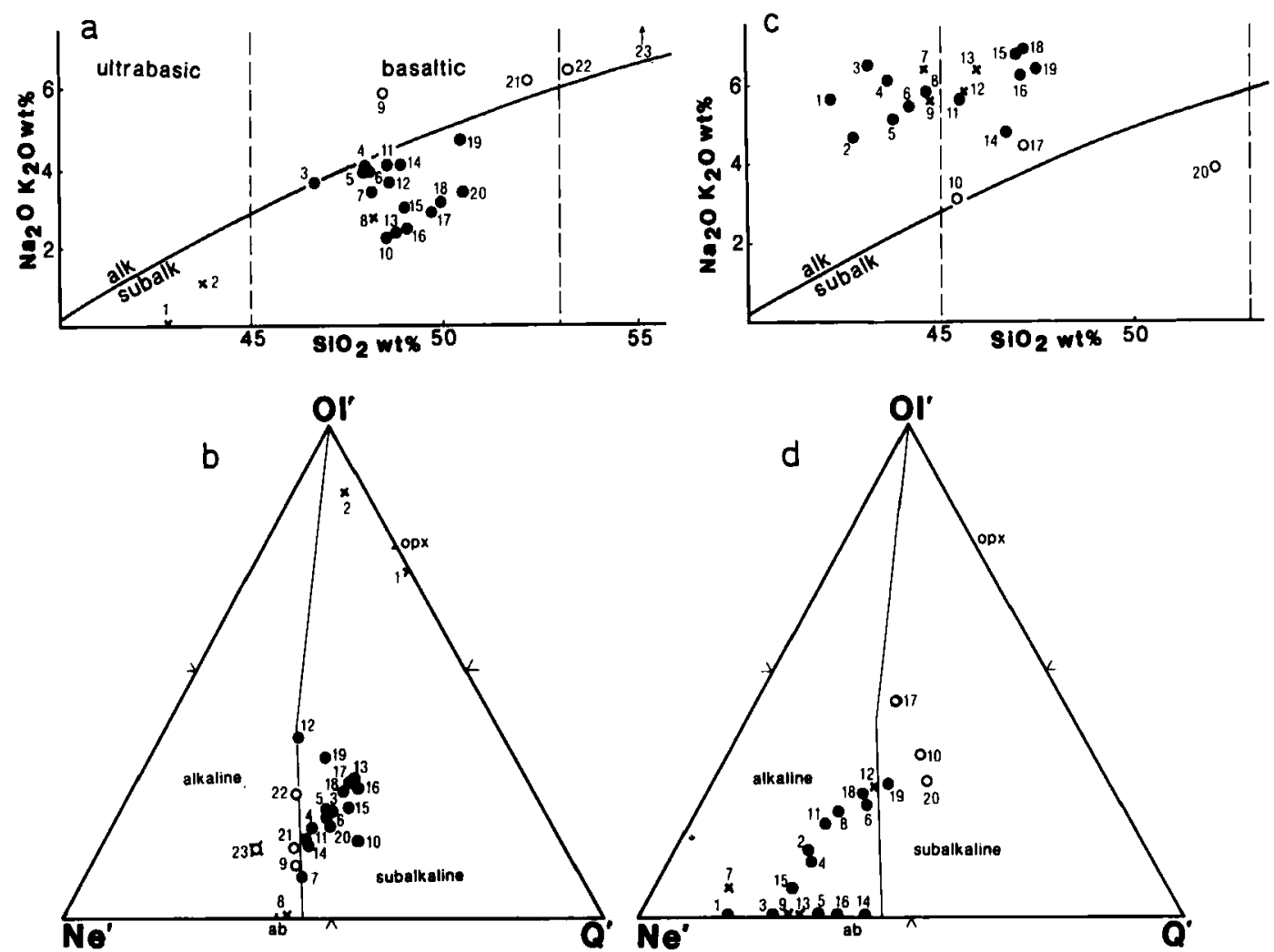

Fig. 4. Alkaline-subalkaline division. Metadiabase-gabbros: $4 a$ and b, Trollheimen volcanics: $4 c$ and d. Division curve and line are from Irvine \& Barager (1971). Crosses: rocks with possible secondary modification and extreme compositions, open circles: alkalic rocks of the metadiabase-gabbros and P-group rocks of the Trollheimen volcanics, dots: common rocks.
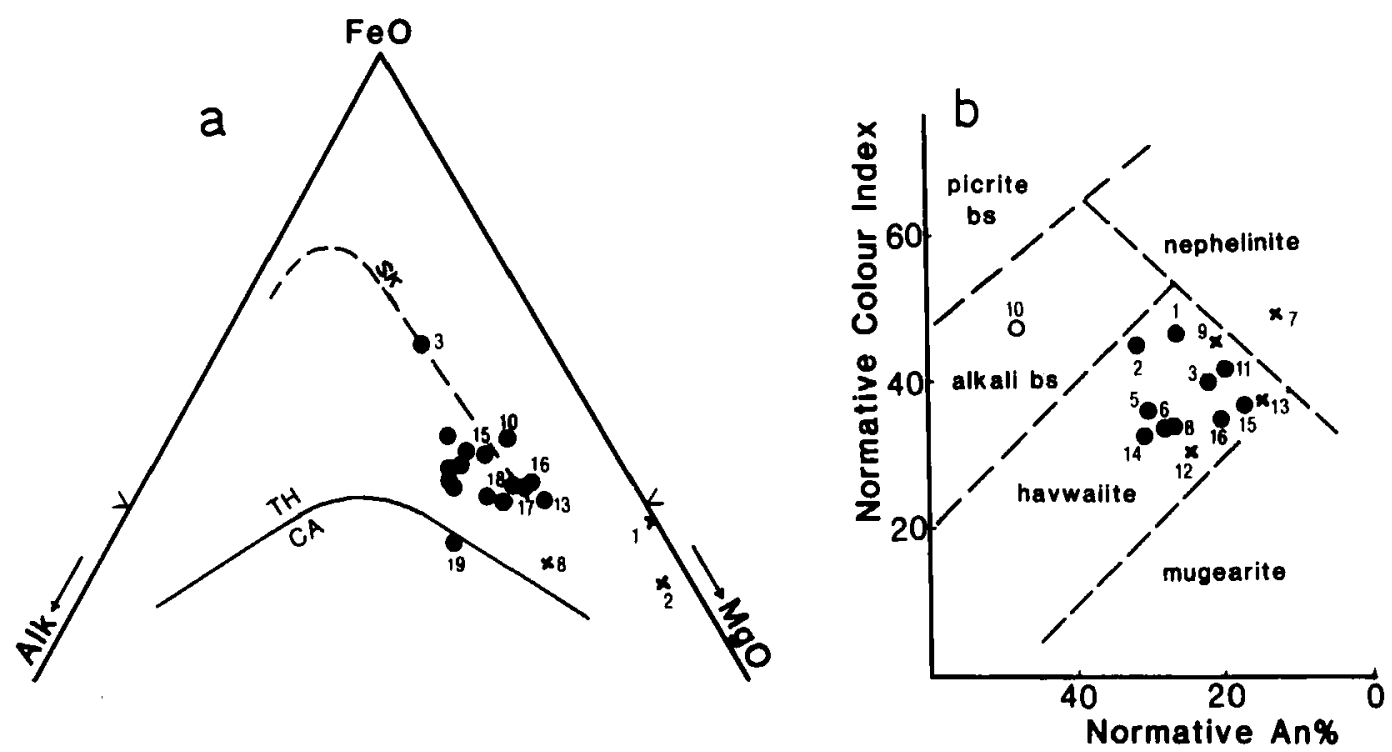

Fig. 5. Classification of the alkaline and subalkaline rocks. Symbols as in Fig. 4. AFM diagram for the metadiabase-gabbros, four alkaline rocks are excluded. Division curve: Irvine \& Barager (1971). b. Classification of the Na-alkaline rocks of the Trollheimen volcanics, excluding four $\mathrm{K}$-alkalic and one subalkalic rocks. 

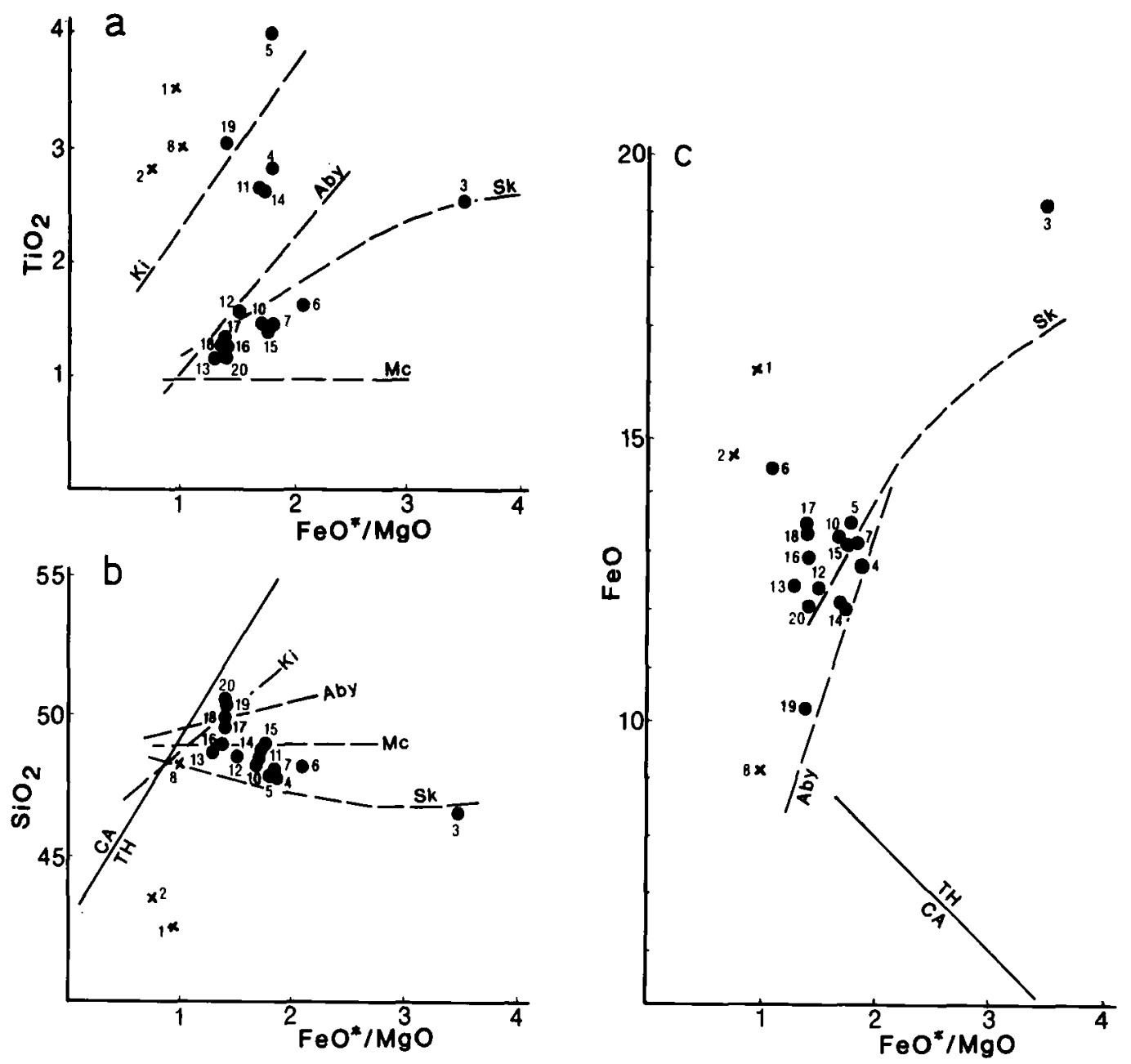

Fig. 6. $\mathrm{FeO}^{*} / \mathrm{MgO}$ variation diagrams for the metadiabase-gabbros. Four alkalic rocks are excluded. Symbols as in Fig. 4. Aby: abyssal tholeiites, Sk: Skaergaard igneous rocks, Ki: kirauea tholeiites, Mc; Macauley basalts. All these trends and TH/CA division line are from Miyashiro (1974).

tite aggregates which give the rock low $\mathrm{CaO}$ and extremely high $\mathrm{K}_{2} \mathrm{O}$. No. 2 has a large amount of serpentine in the groundmass, thus having almost ultramafic composition, although no trace of primary olivine has been seen. No. 1 has no detectable alkalis owing to its simple assemblage of chlorite and dolomite (Fig. 2a). These four samples are of little significance for a general consideration of the original rock.

Four rocks (Nos. 9, 21, 22, 23) fall within the alkaline field on the alkalis-SiO $\mathrm{S}_{2}$ diagram (Fig. 4a). However, Nos. 21 and 22 have only $0.5 \%$ more alkalis than the division curve (Irvine \& Barager 1971), and No. 9 is almost on the division line (Irvine \& Barager 1971) on the normative
Q'-Ne'-Ol' diagram (Fig. 4b). Thus it is reasonable to classify the metadiabase-gabbros as subalkaline. Three Na-alkalic rocks are hawaiite in the normative Colour Index and normative An diagram, while No. 23 is the only K-alkalic rock and has a tristanite composition.

The subalkalic rocks (19 rocks) are all of tholeiitic series with moderate to high $\mathrm{Fe}$-concentration (Fig. 5a), except for No. 19 which is in the calc-alkaline field on the $\mathrm{Al}_{2} \mathrm{O}_{3}$-normative $\mathrm{An}$ diagram.

On the $\mathrm{FeO}^{*} / \mathrm{MgO}$ variation diagrams, $\mathrm{FeO}^{*}\left(=\mathrm{FeO}+0.9 \mathrm{Fe}_{2} \mathrm{O}_{3}\right)$ and $\mathrm{TiO}_{2}$ (Figs. $6 \mathrm{c}$ and a, respectively) show high values as abyssal and oceanic island tholeiites, but they are difficult to 


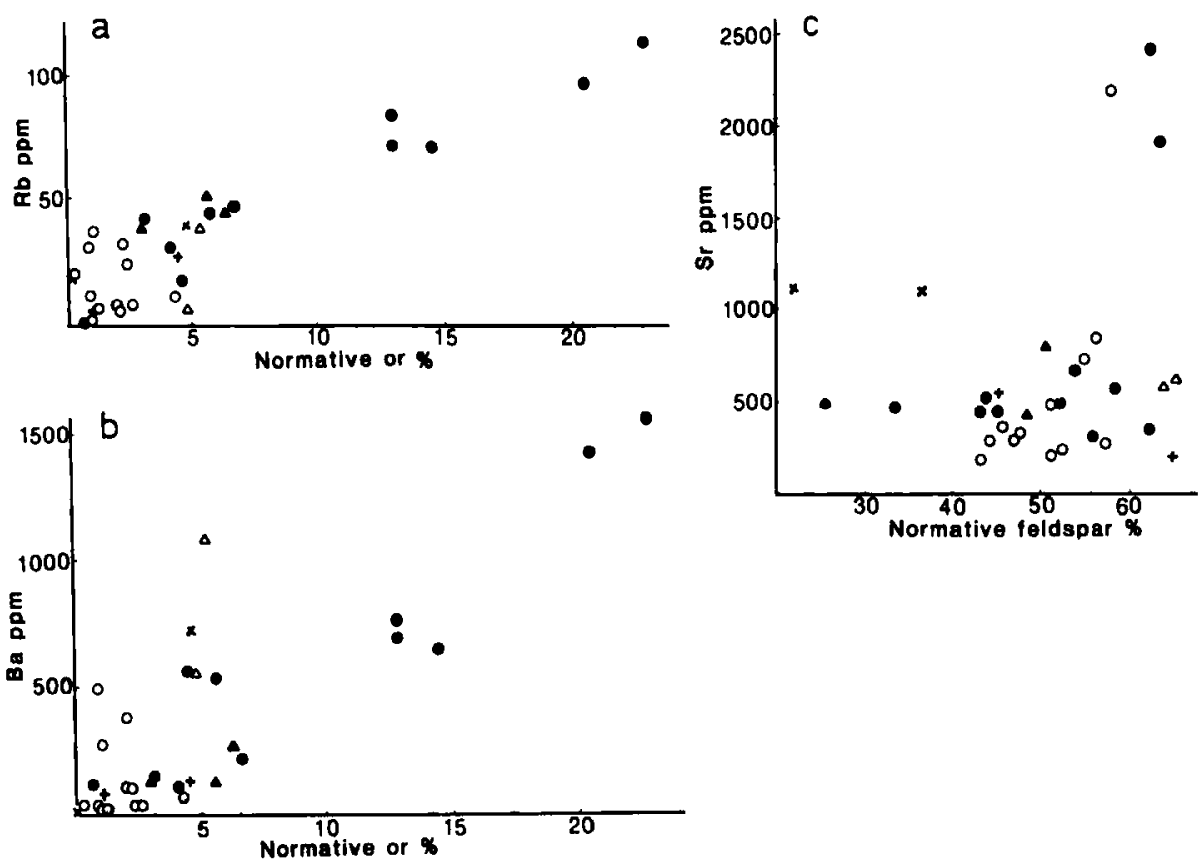

Fig. 7. Relations between the normative feldspars and $\mathrm{Rb}, \mathrm{Ba}, \mathrm{Sr}$ contents. Metadiabase-gabbros. Open circles: tholeites, open triangles: rocks of extreme compositions, diagonal crosses: possible secondary modified rocks. Trollheimen volcanics. Dots: Na-alkaline rocks, solid triangles: subalkaline rocks, crosses: possible secondary modified rocks. a Rb-normative or diagram. b Ba-normative or diagram. c Sr-total normative feldspar diagram.

Table 1. Chemical analyses of metadiabase-gabbros (anhydrous). $\mathrm{TiO}_{2}, \mathrm{~K}_{2} \mathrm{O}$ and $\mathrm{P}_{2} \mathrm{O}_{5}$ in the lowest lines are on the hydrous base.

\begin{tabular}{|c|c|c|c|c|c|c|c|c|c|c|c|}
\hline & 1 & 2 & 3 & 4 & 5 & 6 & 7 & 8 & 9 & 10 & 11 \\
\hline $\mathrm{SiO}_{2}$ & 42.74 & 43.63 & 46.61 & 47.90 & 47.92 & 48.08 & 48.12 & 48.16 & 48.45 & 48.48 & 48.50 \\
\hline $\mathrm{TiO}_{2}$ & 3.52 & 2.80 & 2.54 & 2.84 & 4.01 & 1.63 & 1.46 & 3.00 & 4.52 & 1.44 & 2.64 \\
\hline $\mathrm{Al}_{2} \mathrm{O}_{3}$ & 7.84 & 7.67 & 12.90 & 14.55 & 13.48 & 14.70 & 13.10 & 9.23 & 14.31 & 12.83 & 13.94 \\
\hline $\mathrm{Fe}_{2} \mathrm{O}_{3}$ & 13.25 & 2.24 & 8.09 & 8.34 & 11.05 & 10.77 & 10.25 & 6.91 & 10.21 & 9.58 & 8.72 \\
\hline $\mathrm{FeO}$ & 4.31 & 12.68 & 11.87 & 5.28 & 3.58 & 4.80 & 3.96 & 2.95 & 4.83 & 4.66 & 4.27 \\
\hline $\mathrm{MnO}$ & 0.20 & 0.20 & 0.26 & 0.15 & 0.16 & 0.19 & 0.19 & 0.14 & 0.18 & 0.19 & 0.16 \\
\hline $\mathrm{MgO}$ & 17.32 & 19.85 & 5.45 & 6.88 & 7.54 & 6.87 & 7.09 & 9.18 & 4.45 & 7.69 & 7.14 \\
\hline $\mathrm{CaO}$ & 10.17 & 9.41 & 8.45 & 9.36 & 7.84 & 8.96 & 12.39 & 17.28 & 6.63 & 12.82 & 10.13 \\
\hline $\mathrm{Na}_{2} \mathrm{O}$ & 0.00 & 0.37 & 3.22 & 3.81 & 3.70 & 3.13 & 3.11 & 1.91 & 5.00 & 2.03 & 3.66 \\
\hline $\mathrm{K}_{2} \mathrm{O}$ & 0.00 & 0.72 & 0.39 & 0.19 & 0.16 & 0.71 & 0.19 & 0.79 & 0.88 & 0.17 & 0.36 \\
\hline $\mathrm{P}_{2} \mathrm{O}_{3}$ & 0.66 & 0.43 & 0.21 & 0.70 & 0.55 & 0.14 & 0.13 & 0.45 & 0.85 & 0.12 & 0.48 \\
\hline Total & 100.00 & 100.00 & 100.00 & 100.00 & & 100.00 & 100.00 & 100.00 & 100.00 & 100.00 & 100.00 \\
\hline $\mathbf{R b}$ & 19 & & 24 & 37 & 1.2 & 11 & 5.6 & 39 & 38 & 11 & 4.9 \\
\hline $\mathrm{Sr}$ & 1117 & & 238 & 2188 & 725 & 268 & 205 & 1092 & 620 & 359 & 843 \\
\hline $\mathbf{B a}$ & 17 & & 33 & 280 & 493 & 62 & 18 & 722 & 1074 & 20 & 382 \\
\hline $\mathrm{Zr}$ & 205 & & 121 & 169 & 146 & 88 & 85 & 181 & 338 & 79 & 130 \\
\hline V & 318 & & 544 & 292 & 335 & 356 & 317 & 297 & 358 & 342 & 251 \\
\hline $\mathrm{Cr}$ & 1129 & & 33 & 323 & 160 & 136 & 206 & 397 & 19 & 309 & 73 \\
\hline $\mathrm{Ni}$ & 272 & & 37 & 62 & 122 & 73 & 79 & 84 & 13 & 97 & 84 \\
\hline $\mathbf{Z}_{\mathbf{n}}$ & 135 & & 104 & 122 & 121 & 109 & 77 & 81 & 144 & 95 & 108 \\
\hline $\mathrm{Co}_{0}$ & 69 & & 61 & 42 & 53 & 51 & 44 & 33 & 31 & 49 & 41 \\
\hline $\mathrm{Cu}$ & 30 & & 197 & 7.9 & 68 & 153 & 198 & 5.6 & 16 & 134 & 80 \\
\hline $\mathrm{Pb}$ & 10 & & 3.5 & 7.1 & 3.0 & 5.4 & 6.1 & 5.5 & 5.9 & 4.9 & 4.4 \\
\hline $\mathrm{K}_{2} \mathrm{O}$ & 0.0 & & 0.38 & 0.18 & 0.16 & 0.70 & 0.18 & 0.76 & 0.85 & 0.16 & 0.34 \\
\hline $\mathrm{TiO}_{2}$ & 2.94 & & 2.46 & 2.76 & 3.89 & 1.61 & 1.36 & 2.89 & 4.37 & 1.39 & 2.52 \\
\hline $\mathrm{P}_{2} \mathrm{O}_{5}$ & 0.55 & & 0.28 & 0.60 & 0.53 & 0.14 & 0.12 & 0.43 & 0.82 & 0.12 & 0.48 \\
\hline
\end{tabular}




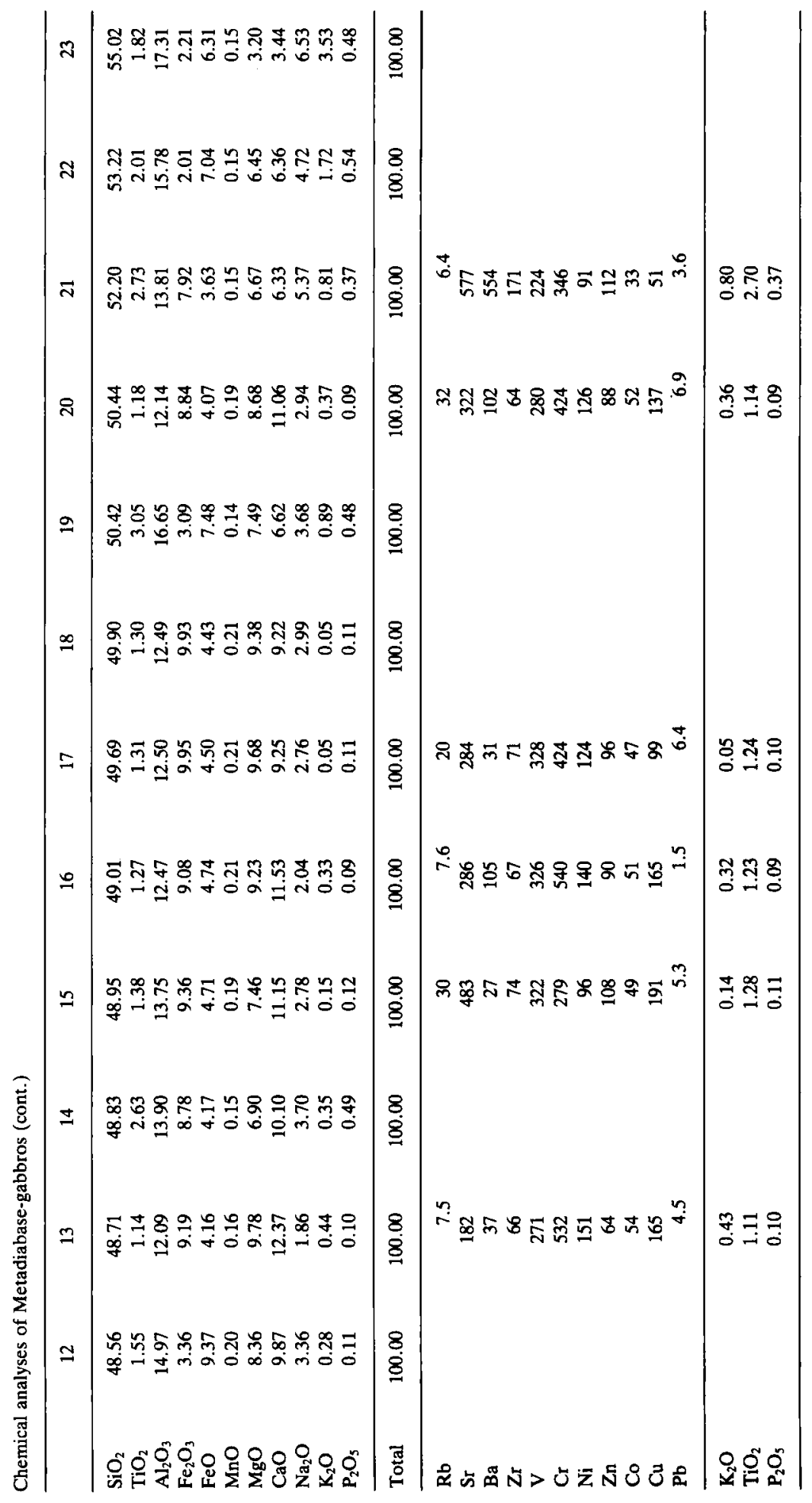



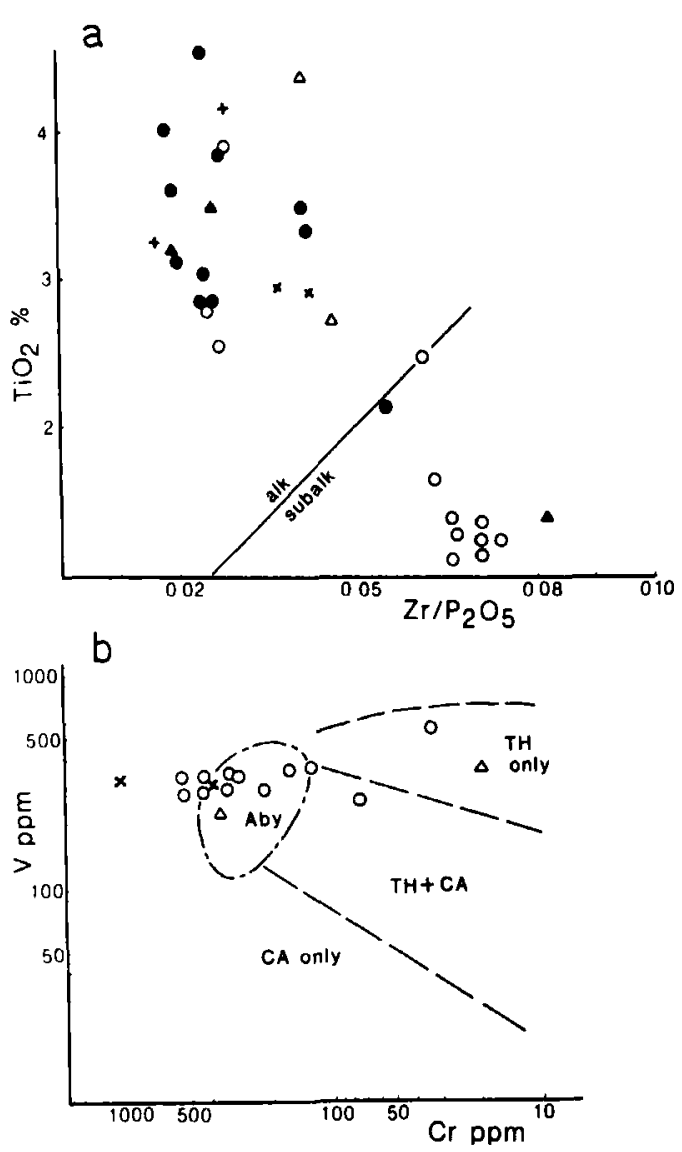

C

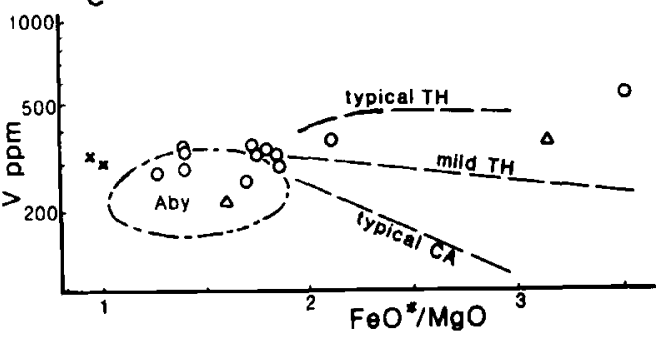

Fig. 8. Classification of the magmatic series by minor and trace elements. Symbols as in $\mathrm{Fig}$. 7, a. $\mathrm{TiO}_{2}-\mathrm{Zr} / \mathrm{P}_{2} \mathrm{O}_{5}$ diagram (Pearce \& Cann 1973). b. V-Cr diagram (Miyashiro \& Shido 1975). c. V-FeO*/MgO diagram (Miyashiro \& Shido 1975). No. 7 of the Trollheimen volcanics is omitted $\left(\mathrm{FeO}^{*} / \mathrm{MgO}=5.32\right)$.

distinguish from the Skaergaard trend due to their low $\mathrm{FeO}^{*} / \mathrm{MgO}$ ratios (Miyashiro 1974). However, this is clarified by minor and trace element ratios presented later.

\section{Trollheimen volcanics}

All rocks with abundant calcite amygdules tend to plot outside the igneous fields of Figs. 3d and e. Thus, those having too high $\mathrm{CaO}$ (Nos. 7, 9, 13) have less significance for a consideration of the original rock. No. 12 should also be left out, due to possible contamination by pelitic material (Fig. 3e).

The P-group rocks (Nos. 10, 17, 20) form a basic group, having less alkalis (Fig. 3f). Many rocks of the B group have spilitic composition in Fig. 3f. Submarine extrusive occurrences and possible Na-zeolites in the primary cavities can explain these high $\mathrm{Na}$ characteristics.

Fig. $4 \mathrm{c}$ shows that all rocks, except those in the P-group, are clearly alkaline. Subtraction of possible secondary $\mathrm{CaO}$, now occurring as amygdules, does not influence the classification.

Only one (No. 20) of the P-group (basic) rocks is subalkaline in Fig. 4c, but all three rocks of this group lie in the subalkaline field on the normative Q'-Ne'-Ol' diagram (Fig. 4d).

Three of the B-group rocks are $\mathrm{K}$-alkalic on the $\mathrm{Na}_{2} \mathrm{O}-\mathrm{K}_{2} \mathrm{O}$ diagram and all the rest are $\mathrm{Na}$ alkalic. The $\mathrm{K}$-alkalic rocks have very small amounts of chlorite, but are rich in sericite (No. 4) and biotite (Nos. 18, 19). Nos. 4 and 18 are trachybasalts, while No. 19 is a $\mathrm{K}$-alkalic basalt on the normative Colour Index-normative An diagram. The Na-alkalic rocks are all hawaiite in composition.

\section{Minor and trace elements}

Eleven trace elements have been analysed by the XRF method for 16 samples from each of two rock groups. The data are presented in Tables 1 and 2, with three minor elements $\left(\mathrm{TiO}_{2}, \mathrm{~K}_{2} \mathrm{O}\right.$ and $\mathrm{P}_{2} \mathrm{O}_{5}$ ) on the hydrous base.

$\mathrm{Rb}$ and $\mathrm{Ba}$ contents show large variations relating essentially to the normative $\mathrm{K}$-feldspar contents (actually micas) of the rocks (Figs. 7a and $b$ ) in the Trollheimen volcanics, but not in the metadiabase-gabbros. Sr contents also show a large variation. A positive relation with increasing total normative feldspars can be seen in the metadiabase-gabbros, while those of the Trollheimen volcanics are nearly constant (Fig. 7c). Three rocks, No. 4 of the metadiabase-gabbros and nos. 18, 19 of the Trollheimen volcanics, have very high $\mathrm{Sr}$ contents.

Among "immobile" elements, $\mathrm{Cr}, \mathrm{Ni}, \mathrm{Cu}$ and $\mathrm{Pb}$ have large variations. the $\mathrm{TiO}_{2}-\mathrm{Zr} / \mathrm{P}_{2} \mathrm{O}_{5}$ diagram (Fig. 8a) conforms with the alkaline nature of the Trollheimen volcanics and the subalkaline for the metadiabase-gabbros, although there are some anomalies, i.e., Nos. $3,4,5,11$ of the latter. 
Table 2. Chemical analyses of Troltheimen volcanics (anhydrous). $\mathrm{TiO}_{2}, \mathrm{~K}_{2} \mathrm{O}$ and $\mathrm{P}_{2} \mathrm{O}_{5}$ in the lowest lines are on the hydrous base.

\begin{tabular}{|c|c|c|c|c|c|c|c|c|c|c|}
\hline & 1 & 2 & 3 & 4 & 5 & 6 & 7 & 8 & 9 & 10 \\
\hline $\mathrm{SiO}_{2}$ & 42.13 & 42.73 & 43.18 & 43.63 & 43.77 & 44.19 & 44.57 & 44.60 & 44.69 & 45.40 \\
\hline $\mathrm{TiO}_{2}$ & 3.20 & 3.27 & 4.07 & 4.30 & 3.38 & 4.78 & 3.55 & 4.13 & 2.56 & 3.66 \\
\hline $\mathrm{Al}_{2} \mathrm{O}_{3}$ & 13.81 & 13.74 & 13.57 & 14.39 & 15.23 & 14.10 & 12.56 & 15.52 & 12.97 & 12.67 \\
\hline $\mathrm{Fe}_{2} \mathrm{O}_{3}$ & 7.41 & 8.79 & 7.90 & 6.53 & 10.48 & 7.72 & 2.04 & 6.36 & 5.20 & 8.95 \\
\hline $\mathrm{FeO}$ & 7.96 & 9.07 & 7.53 & 8.33 & 3.47 & 9.73 & 13.40 & 8.03 & 7.63 & 6.26 \\
\hline $\mathrm{MnO}$ & 0.16 & 0.14 & 0.11 & 0.10 & 0.31 & 0.12 & 0.18 & 0.13 & 0.16 & 0.19 \\
\hline $\mathrm{MgO}$ & 4.96 & 5.80 & 4.31 & 4.24 & 3.73 & 5.74 & 2.86 & 6.45 & 3.91 & 9.43 \\
\hline $\mathrm{CaO}$ & 14.02 & 11.03 & 11.04 & 10.53 & 13.16 & 6.82 & 13.17 & 7.85 & 16.38 & 9.31 \\
\hline $\mathrm{Na}_{2} \mathrm{O}$ & 4.43 & 4.14 & 4.34 & 3.64 & 4.98 & 4.45 & 5.41 & 5.07 & 4.88 & 2.56 \\
\hline $\mathrm{K}_{2} \mathrm{O}$ & 1.11 & 0.52 & 2.13 & 2.39 & 0.12 & 0.95 & 0.92 & 0.69 & 0.64 & 0.49 \\
\hline $\mathrm{P}_{2} \mathrm{O}_{5}$ & 0.82 & 0.76 & 1.81 & 1.91 & 1.30 & 1.40 & 1.34 & 1.16 & 0.98 & 1.07 \\
\hline Total & 100.00 & 100.00 & 100.00 & 100.00 & 100.00 & 100.00 & 100.00 & 100.00 & 100.00 & 100.00 \\
\hline $\mathrm{Rb}$ & 47 & 42 & 71 & 71 & 0 & 44 & 51 & 30 & & 38 \\
\hline Sr & 465 & 443 & 517 & 487 & 664 & 346 & 492 & 311 & & 424 \\
\hline $\mathrm{Ba}$ & 217 & 142 & 682 & 643 & 119 & 532 & 128 & 108 & & 133 \\
\hline $\mathrm{Zr}$ & 175 & 165 & 296 & 311 & 236 & 321 & 233 & 291 & & 267 \\
\hline $\mathrm{V}$ & 322 & 378 & 342 & 357 & 314 & 516 & 335 & 369 & & 342 \\
\hline $\mathrm{Cr}$ & 341 & 396 & 114 & 124 & 162 & 280 & 161 & 346 & & 299 \\
\hline $\mathrm{Ni}$ & 188 & 183 & 74 & 73 & 111 & 168 & 99 & 155 & & 155 \\
\hline $\mathrm{Zn}$ & 147 & 162 & 151 & 146 & 168 & 151 & 107 & 169 & & 160 \\
\hline Co & 50 & 57 & 43 & 40 & 40 & 57 & 37 & 55 & & 52 \\
\hline $\mathrm{Cu}$ & 76 & 66 & 27 & 42 & 82 & 50 & 75 & 25 & & 73 \\
\hline $\mathrm{Pb}$ & 6.2 & 4.9 & 1.9 & 3.5 & 5.5 & 4.4 & 5.2 & 7.5 & & 6.8 \\
\hline $\mathrm{K}_{2} \mathrm{O}$ & 0.98 & 0.48 & 1.88 & 2.23 & 0.11 & 0.90 & 0.83 & 0.64 & & 0.47 \\
\hline $\mathrm{TiO}_{2}$ & 2.83 & 3.02 & 3.60 & 4.01 & 3.11 & 4.54 & 3.19 & 3.84 & & 3.49 \\
\hline \multirow[t]{2}{*}{$\mathrm{P}_{2} \mathrm{O}_{5}$} & 0.73 & 0.70 & 1.60 & 1.78 & 1.20 & 1.33 & 1.20 & 1.08 & & 1.02 \\
\hline & 11 & 12 & 13 & 14 & 15 & 16 & 17 & 18 & 19 & 20 \\
\hline $\mathrm{SiO}_{2}$ & 45.49 & 45.56 & 45.93 & 46.65 & 46.91 & 47.05 & 47.10 & 47.18 & 47.47 & 52.04 \\
\hline $\mathrm{TiO}_{2}$ & 3.98 & 4.43 & 3.55 & 3.14 & 2.78 & 3.44 & 2.31 & 3.63 & 3.52 & 1.43 \\
\hline $\mathrm{Al}_{2} \mathrm{O}_{3}$ & 13.33 & 16.10 & 13.82 & 13.47 & 14.86 & 13.89 & 10.11 & 14.37 & 14.10 & 12.85 \\
\hline $\mathrm{Fe}_{2} \mathrm{O}_{3}$ & 3.63 & 6.54 & 3.55 & 9.53 & 5.57 & 9.86 & 11.11 & 7.87 & 8.18 & 7.18 \\
\hline $\mathrm{FeO}$ & 11.86 & 8.79 & 7.63 & 3.60 & 8.30 & 3.79 & 3.13 & 5.31 & 5.18 & 3.52 \\
\hline $\mathrm{MnO}$ & 0.11 & 0.09 & 0.13 & 0.21 & 0.15 & 0.20 & 0.18 & 0.17 & 0.17 & 0.14 \\
\hline $\mathrm{MgO}$ & 4.90 & 6.88 & 3.14 & 4.13 & 3.97 & 3.65 & 12.85 & 6.61 & 6.38 & 9.60 \\
\hline $\mathrm{CaO}$ & 9.81 & 4.59 & 14.03 & 13.52 & 9.81 & 10.84 & 8.28 & 6.77 & 7.43 & 9.22 \\
\hline $\mathrm{Na}_{2} \mathrm{O}$ & 5.24 & 5.04 & 6.11 & 4.00 & 6.08 & 5.19 & 2.37 & 3.46 & 2.58 & 2.76 \\
\hline $\mathrm{K}_{2} \mathrm{O}$ & 0.28 & 0.76 & 0.29 & 0.76 & 0.64 & 1.00 & 2.06 & 3.43 & 3.77 & 1.06 \\
\hline $\mathrm{P}_{2} \mathrm{O}_{5}$ & 1.36 & 1.23 & 1.91 & 0.99 & 0.91 & 1.09 & 0.50 & 1.25 & 1.23 & 0.21 \\
\hline Total & 100.00 & 100.00 & 100.00 & 100.00 & 100.00 & 100.00 & 100.00 & 100.00 & 100.00 & 100.00 \\
\hline $\mathrm{Rb}$ & & 27 & 4.7 & 17 & & & 84 & 96 & 113 & 44 \\
\hline $\mathrm{Sr}$ & & 197 & 546 & 571 & & & 435 & 1914 & 2417 & 803 \\
\hline $\mathrm{Ba}$ & & 128 & 80 & 554 & & & 764 & 1409 & 1642 & 268 \\
\hline $\mathrm{Zr}$ & & 321 & 286 & 231 & & & 254 & 494 & 482 & 164 \\
\hline $\mathrm{V}$ & & 425 & 243 & 287 & & & 231 & 305 & 302 & 175 \\
\hline $\mathrm{Cr}$ & & 374 & 46 & 210 & & & 698 & 92 & 87 & 844 \\
\hline $\mathrm{Ni}$ & & 170 & 38 & 110 & & & 353 & 70 & 72 & 208 \\
\hline $\mathrm{Zn}$ & & 181 & 124 & 110 & & & 120 & 158 & 156 & 95 \\
\hline Co & & 61 & 28 & 31 & & & 63 & 36 & 32 & 39 \\
\hline $\mathrm{Cu}$ & & 24 & 20 & 23 & & & 45 & 30 & 28 & 42 \\
\hline $\mathrm{Pb}$ & & 6.1 & 7.1 & 4.1 & & & 8.1 & 7.7 & 7.7 & 8.6 \\
\hline $\mathrm{K}_{2} \mathrm{O}$ & & 0.71 & 0.17 & 0.69 & & & 1.89 & 3.29 & 3.56 & 1.03 \\
\hline $\mathrm{TiO}_{2}$ & & 4.15 & 3.24 & 2.83 & & & 2.12 & 3.48 & 3.32 & 1.39 \\
\hline $\mathrm{P}_{2} \mathrm{O}_{5}$ & & 1.15 & 1.74 & 0.89 & & & 0.46 & 1.20 & 1.16 & 0.20 \\
\hline
\end{tabular}




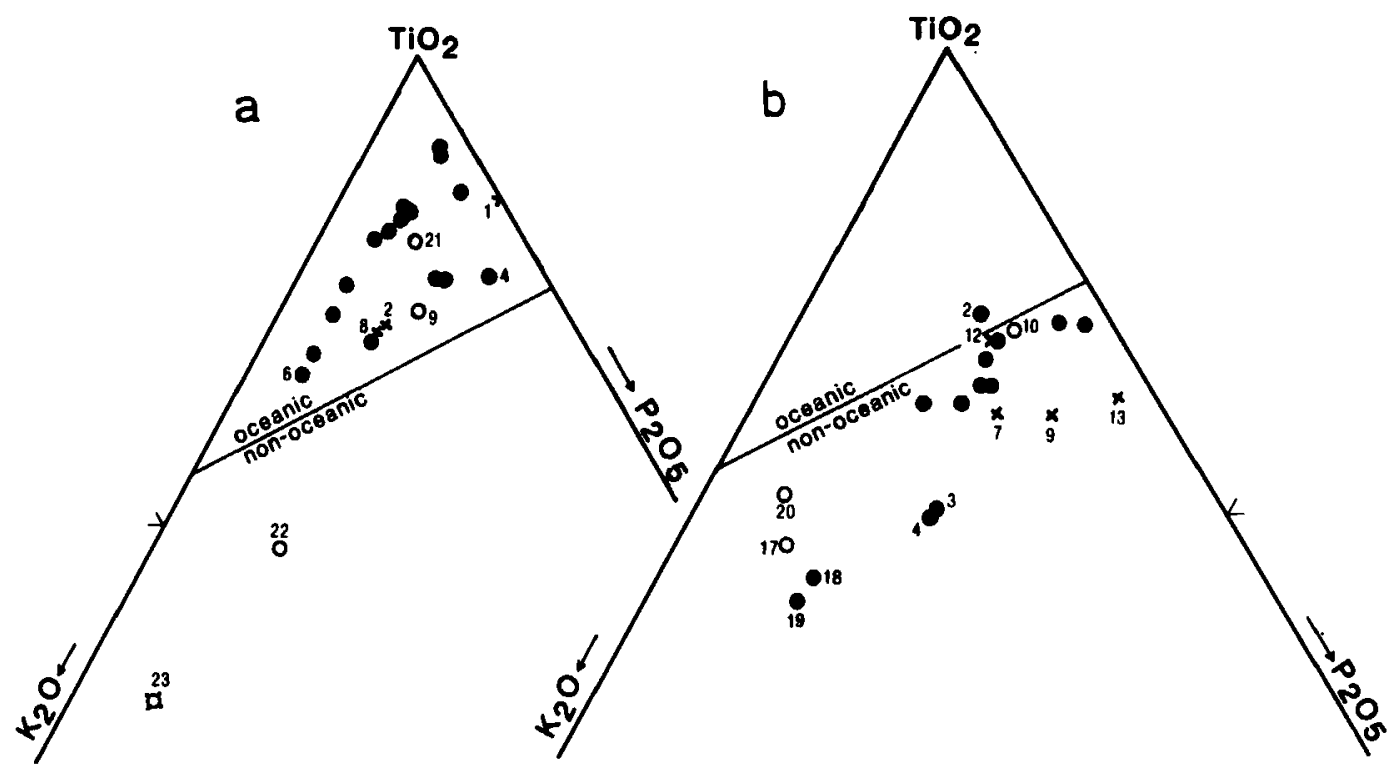

Fig. 9. $\mathrm{TiO}_{2}-\mathrm{K}_{2} \mathrm{O}-\mathrm{P}_{2} \mathrm{O}_{5}$-diagrams (Pearce \& Cann 1973). Symbols as in Fig. 4. a. Metadiabase-gabbros. b. Trollheimen volcanics.

The tholeiitic nature of the metadiabase-gabbros is supported by the $\mathrm{V}-\mathrm{Cr}$ and the $\mathrm{V}-\mathrm{FeO} * \mathrm{MgO}$ relations (Figs. $8 \mathrm{~b}$ and c) (Miyashiro \& Shido 1975).

Minor element ratios of $\mathrm{TiO}_{2}-\mathrm{K}_{2} \mathrm{O}-\mathrm{P}_{2} \mathrm{O}_{5}$ (Figs. $9 \mathrm{a}$ and $\mathrm{b}$ ) clearly show that the metadiabase-gabbros are oceanic, while in contrast the Trollheimen volcanics are non-oceanic (Pearce \& Cann 1973). Further information on the tectonic setting of the latter is not available yet, but the nature of contemporaneous sediments suggests a shallow shelf condition.

Minor and trace element ratios are also examined on Figs. 10a-g in relation to various tectonic settings. The $\mathrm{Zr}$-Sr diagram (Fig. 10a) shows a clear separation of the two rock groups. The majority of the metadiabase-gabbros have $\mathrm{Zr}$ contents similar to OFB, but the Sr contents are distinctly higher than for OFB (Pearce \& Cann 1973). The latter may relate to the amounts of feldspars recrystallized during metamorphism (Fig. 7c). Some rocks, Nos. 1 and 2 of the Trollheimen volcanics and Nos. 5 and 11 of the metadiabase-gabbros, have $\mathrm{Zr} / \mathrm{Sr}$ ratios intermediate between the two groups. In the field they occur near the boundary of the two formations (Fig. 1).

$\mathrm{Sr}$ anomaly is also considered in the $\mathrm{Ti} / 100$ $\mathrm{Zr}$-Sr/2 diagram (Fig. 10g). Most metadiabasegabbros plot in the field of island arc basalts and many of the Trollheimen volcanics in the ocean floor basalts. However, this may be liable since the $\mathrm{Sr}$ contents show large variation by unknown reason and most "immobile" trace elements show different results as described below.

Figs. 10b-f enable discrimination of tholeiitic rocks from different tectonic settings, thus only effective for the metadiabase-gabbros. However, the Na-alkalic Trollheimen volcanics are also shown for comparison.

$\mathrm{FeO}^{*} / \mathrm{MgO}$ variation diagrams for $\mathrm{Ni}$ and $\mathrm{Cr}$ (Figs. 10b and c) show that the contents of these two elements in the metadiabase-gabbros fit well with abyssal basalts (Miyashiro \& Shido 1975). All metadiabase-gabbros are plotted in the OFB field in the Ti-Cr, $\mathrm{Ti}-\mathrm{Zr}$ and $\mathrm{Ti} / \mathrm{Cr}-\mathrm{Ni}$ diagrams (Figs. 10d, e, and $f$ ), and can be distinguished from the island arc volcanics (Pearce \& Cann 1973; Pearce 1975; Beccaluva et al. 1979).

The majority of the plots show a linear distribution in all these diagrams, suggesting a magmatic differentiation trend without strong secondary modification on these "immobile" elements during metamorphism. Both the metadiabase-gabbros and Trollheimen volcanics are characterised by clinopyroxene fractionation (Figs. 11a and b). A plagioclase fractionation is exhibited by the pegmatitic rocks of the metadiabase-gabbros (Fig. 11a). 

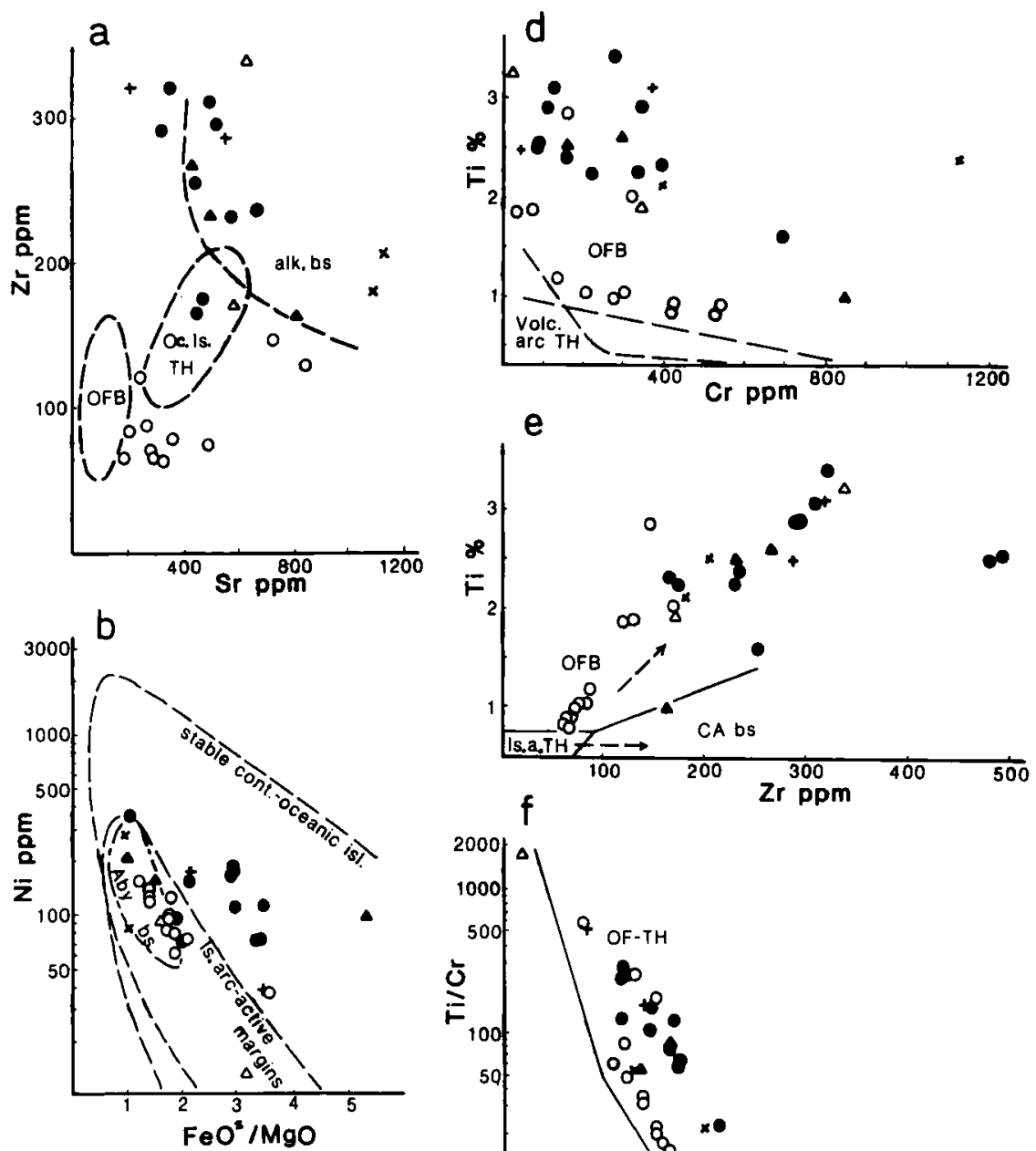

C
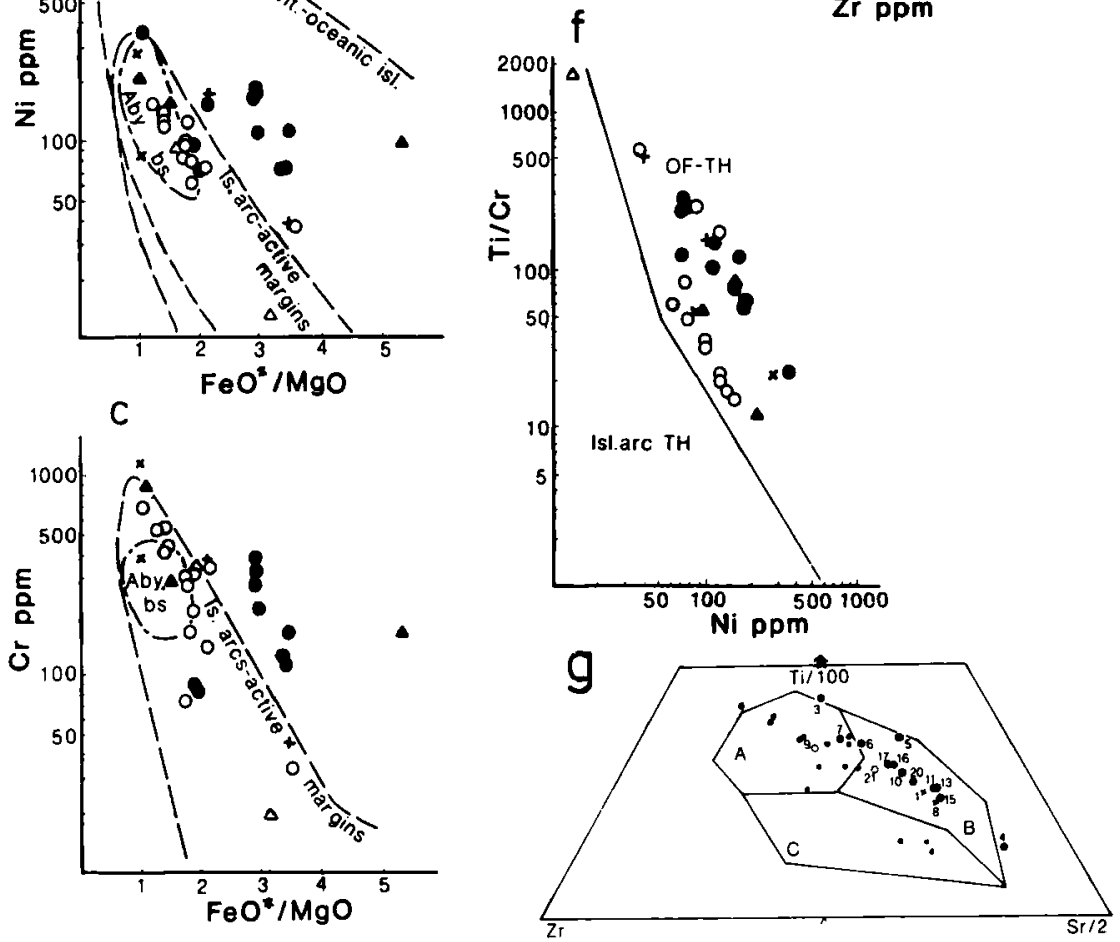

Fig. 10. Estimation of the tectonic settings from the minor and trace element contents. Symbols as in Fig. 7, except for $10 \mathrm{~g}$. a. $\mathrm{Zr}$-Sr diagram (Pearce \& Cann 1973). No. 4 of the metadiabase-gabbros and Nos. 18 and 19 of the Trollheimen volcanics are omitted $(\mathrm{Sr}=2188 \mathrm{ppm}, 1914 \mathrm{ppm}$ and $2417 \mathrm{ppm}$, respectively). b. $\mathrm{Ni}-\mathrm{FeO} * / \mathrm{MgO}$ diagram (Miyashiro \& Shido 1975). c. Cr$\mathrm{FeO}^{*} / \mathrm{MgO}$ diagram (Miyashiro \& Shido 1975). d. Ti-Cr diagram (Pearce 1975, modified by Garcia 1978). e. Ti-Zr diagram (Pearce \& Cann 1973). Arrows indicate normal differentiation trend. f. Ti/Cr-Ni diagram (Beccaluva et al. 1979). g. Ti/100-ZrSr/2 diagram (Pearce \& Cann 1973). Metadiabase-gabbros: numbered symbols as in Fig. 4. Trollheimen volcanics: small dots without number. A: ocean floor basalts, B: low $\mathrm{K}$ basalts of island arcs, $\mathrm{C}$ : calc-alkaline basalts. 
a

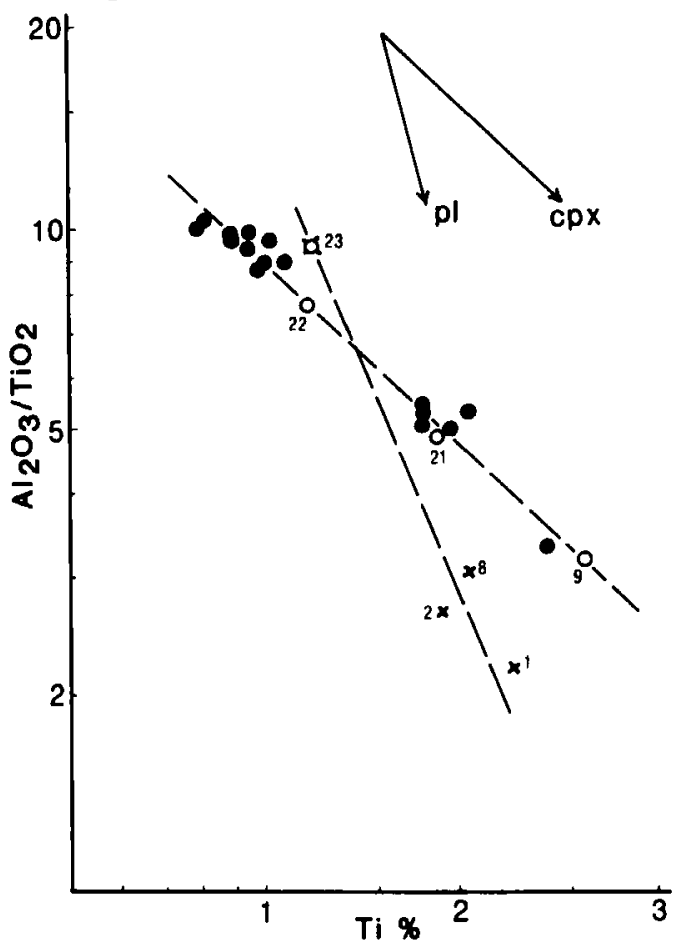

b

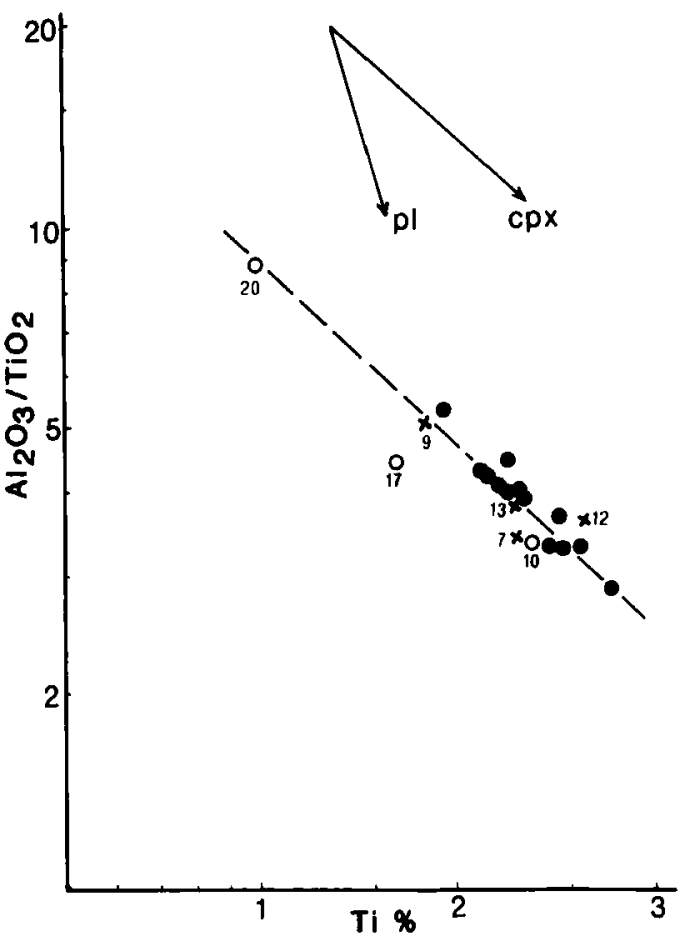

Fig. 11. Fractional crystallization of the rocks. Symbols as in Fig. 4. Vectors for plagioclase (pl) and clinopyroxene (cpx) indicate 50\% fractionation (Pearce \& Flower 1977). a. Metadiabase-gabbros. b. Trollheimen volcanics.

The minor and trace elements are normalized to those of the average MORB (see the caption of Table 3) and are shown in Tables 3a and $3 b$. The tables show that average deviation of the "immobile" minor and trace elements contents (excluding $\mathrm{K}_{2} \mathrm{O}, \mathrm{Rb}, \mathrm{Sr}, \mathrm{Ba}$ and $\mathrm{Pb}$ ) from the average MORB is small in the metadiabase-gabbros; average normalized number $=1.4($ on $=$ 0.3 ), excluding four rocks of possible strong secondary modification. The average normalized members for the Trollheimen volcanics are: $11 \mathrm{Na}$ alkaline rocks $=2.5(\sigma \mathrm{n}=0.4)$ and 3 subalkaline rocks $=2.4(\sigma \mathrm{n}=0.5)$. These statistics also show that the metadiabase-gabbros have similar minor and trace element behaviours to MORB.

The main reason for the high normalized numbers for the Trollheimen volcanics is their high $\mathrm{P}_{2} \mathrm{O}_{5}$ contents. This may be caused by high volatile concentration in the later stage of consolidation as represented by abundant amygdules, and agree with the postulated non-oceanic nature of these rocks (Fig. 9b).

\section{Discussion}

Remarkable differences exist between the metadiabase-gabbros and the Trollheimen volcanics in the present area:

\begin{tabular}{|c|c|c|}
\hline & metadiabase-gabbros & Trollheimen volcanics \\
\hline occurrence & $\begin{array}{l}\text { discontinuous lenses } \\
\text { in the CAV } \mathrm{fm}\end{array}$ & $\begin{array}{l}\text { extrusives in the Q-Sh } \\
\mathrm{fm} \text {. }\end{array}$ \\
\hline $\begin{array}{l}\text { associated } \\
\text { country rocks }\end{array}$ & calc-sh, ss and is & sandy sh and qtz \\
\hline $\begin{array}{l}\text { megascopic } \\
\text { texture }\end{array}$ & $\begin{array}{l}\text { metadiabases and } \\
\text { gabbros }\end{array}$ & $\begin{array}{l}\text { lavas, pyroclastics. } \\
\text { tuffs }\end{array}$ \\
\hline $\begin{array}{l}\text { textures under } \\
\text { microscope }\end{array}$ & $\begin{array}{l}\text { porphyritic, ophitic. } \\
\text { gabbroic, pegmatitic }\end{array}$ & $\begin{array}{l}\text { porphyritic, doloritic. } \\
\text { trachy-basaltic }\end{array}$ \\
\hline $\begin{array}{l}\text { primary bulk } \\
\text { compositions }\end{array}$ & $\begin{array}{l}\text { tholeiitic serics with } \\
\text { moderate-high } \mathrm{Fe}\end{array}$ & $\begin{array}{l}\text { Na-alkaline + (calc } \\
\text { alkaline?) }\end{array}$ \\
\hline $\begin{array}{l}\text { minor \& trace } \\
\text { elements }\end{array}$ & oceanic, MORB type & $\begin{array}{l}\text { non-oceanic. } \\
\text { intraplate type? }\end{array}$ \\
\hline metamorphism & $\begin{array}{l}\text { mostly act-ep-bi-alb } \\
\text { assemblage }\end{array}$ & $\begin{array}{l}\text { transition from chl. } \\
\text { alb to act-ep-bi-alb } \\
\text { assemblage }\end{array}$ \\
\hline
\end{tabular}


It will be possible to use these differences for the correlation of the stratigraphic units, including basic igneous rocks, in the Middle Hecla Hoek succession of western Spitsbergen.

However, it is still unclear whether these igneous rocks are really restricted in occurrence in each of the two formations. The P-group rocks of the Trollheimen volcanics may be grouped in the metadiabase-gabbros, on account of their mode of occurrence and bulk chemistry, although their $\mathrm{SiO}_{2}$ contents are higher than that of the latter. Some metadiabase lenses occurring lower than the lower limestone member of the CAV formation in the western slope of Kinnefjellet may prove that these rocks also occur in the QSh formation (Fig. 1). On the other hand, some green phyllite beds are distributed in the upper part of the CAV formation on the northern coast of St. Jonsfjorden, and they may be metamorphosed extrusive rocks. If true, these two different basic rocks simply reflect the difference between the extrusive volcanics contemporaneous with sedimentation and the intrusive rocks whose age is unknown, but at least older than the main Caledonian metamorphism. Some green rocks have been known from Eocambrian tilloid successions, but their chemistry has not been studied yet.

The metadiabase-gabbros have strong chemical similarities with the MORB. However, the surrounding lower limestone member of the CAV formation does not show any deep sea sedimentary environment; on the contrary, it has large reef-like lensoid masses of brecciated and oolitic-pisolitic limestones in several places. Alternating calcareous shales are less sorted and have many sandy beds. Thus, the CAV formation is a shallow marine sedimentary succession and does not conform with the deep sea nature of the metadiabase-gabbros. This fact indirectly suggests that the latter is intrusive and is later than the sedimentation of the adjacent sediments.

The association of shallow marine sediments with deep sea basic igneous rocks can be explained by a progressive advance of shallow marine shelf conditions onto a deep sea mid-oceanic crust by the drifting of a continent. Thus, the shallow marine sediments formed at an earlier stage were subsequently intruded by oceanic igneous rocks. If this is the case, the contact between the sup-

Table $3 a$. Minor and trace elements of the Metadiabase-gabbros, normalized against the average MORB.

\begin{tabular}{lrrrrrrrrrrrrrrrrrrr}
\hline & 1 & 3 & 4 & 5 & 6 & 7 & 8 & 9 & 10 & 11 & 13 & 15 & 16 & 17 & 20 & 21 & $\bar{x}$ & on \\
\hline $\mathrm{Rb}$ & 9.5 & 12.0 & 18.5 & 0.6 & 5.5 & 2.8 & 19.5 & 19.0 & 5.5 & 2.5 & 3.8 & 15.0 & 3.8 & 10.0 & 16.0 & 3.2 & 8.0 & 6.8 \\
$\mathrm{Sr}$ & 9.3 & 2.0 & 18.2 & 6.0 & 2.2 & 1.7 & 9.1 & 5.2 & 3.0 & 7.0 & 1.5 & 4.0 & 2.4 & 2.4 & 2.7 & 4.8 & 4.4 & 4.5 \\
$\mathrm{Ba}$ & 0.9 & 1.7 & 14.0 & 24.7 & 3.1 & 0.9 & 36.1 & 53.7 & 1.0 & 19.1 & 1.9 & 1.4 & 5.3 & 1.6 & 5.1 & 27.7 & 6.7 & 7.7 \\
$\mathrm{Zr}$ & 2.3 & 1.3 & 1.9 & 1.6 & 1.0 & 0.9 & 2.0 & 3.8 & 0.9 & 1.4 & 0.7 & 0.8 & 0.7 & 0.8 & 0.7 & 1.9 & 1.1 & 0.4 \\
$\mathrm{~V}$ & 1.4 & 2.3 & 1.3 & 1.4 & 1.5 & 1.4 & 1.3 & 1.5 & 1.5 & 1.1 & 1.2 & 1.4 & 1.4 & 1.4 & 1.2 & 1.0 & 1.4 & 0.3 \\
$\mathrm{Cr}$ & 4.5 & 0.1 & 1.3 & 0.6 & 0.5 & 0.8 & 1.6 & 0.1 & 1.2 & 0.3 & 2.1 & 1.1 & 2.2 & 1.7 & 1.7 & 1.4 & 1.1 & 0.7 \\
$\mathrm{Ni}$ & 2.1 & 0.3 & 0.5 & 1.0 & 0.6 & 0.6 & 0.7 & 0.1 & 0.8 & 0.7 & 1.2 & 0.7 & 1.1 & 1.0 & 1.0 & 0.7 & 0.8 & 0.3 \\
$\mathrm{Zn}$ & 1.9 & 1.4 & 1.7 & 1.7 & 1.5 & 1.1 & 1.1 & 2.0 & 1.3 & 1.5 & 0.9 & 1.5 & 1.3 & 1.3 & 1.2 & 1.6 & 1.4 & 0.3 \\
$\mathrm{Co}$ & 1.5 & 1.4 & 0.9 & 1.2 & 1.1 & 1.0 & 0.7 & 0.7 & 1.1 & 0.9 & 1.2 & 1.1 & 1.1 & 1.0 & 1.2 & 0.7 & 1.1 & 0.1 \\
$\mathrm{Cu}$ & 11.1 & 2.9 & 0.1 & 1.0 & 2.3 & 3.0 & 0.1 & 0.2 & 2.0 & 1.2 & 2.5 & 2.9 & 2.5 & 1.5 & 2.1 & 0.8 & 1.6 & 1.0 \\
$\mathrm{~Pb}$ & 0 & 3.9 & 7.9 & 3.3 & 6.0 & 6.8 & 6.1 & 6.6 & 5.4 & 4.9 & 5.0 & 5.9 & 1.7 & 7.1 & 7.7 & 4.0 & 5.8 & 2.1 \\
\hline $\mathrm{K}=$ & 2.0 & 3.2 & 1.5 & 1.3 & 5.8 & 1.5 & 6.3 & 7.1 & 1.3 & 2.8 & 3.6 & 1.2 & 2.7 & 0.4 & 3.0 & 6.7 & 2.4 & 1.4 \\
$\mathrm{TiO} \mathrm{O}_{2}$ & 4.6 & 1.6 & 1.8 & 2.6 & 1.1 & 0.9 & 1.9 & 2.9 & 0.9 & 1.7 & 0.7 & 0.9 & 0.8 & 0.8 & 0.8 & 1.8 & 1.2 & 0.6 \\
$\mathrm{P}_{2} \mathrm{O}_{5}$ & 2.3 & 1.7 & 5.7 & 4.4 & 1.2 & 1.0 & 3.6 & 6.8 & 1.0 & 4.0 & 0.8 & 0.9 & 0.8 & 0.8 & 0.8 & 3.1 & 1.9 & 1.7 \\
$\overline{\mathrm{x}}$ & 1.3 & 1.4 & 1.7 & 1.7 & 1.2 & 1.2 & 1.4 & 2.0 & 1.2 & 1.4 & 1.3 & 1.3 & 1.3 & 1.1 & 1.2 & 1.4 & 1.4 & 0.3 \\
$\delta \mathrm{n}$ & & 0.8 & 1.5 & 1.1 & 0.5 & 0.7 & 1.0 & 2.1 & 0.4 & 1.0 & 0.6 & 0.6 & 0.6 & 0.3 & 0.4 & 0.7 & \\
\hline
\end{tabular}

MORB averages: $\mathrm{Rb}=2 \mathrm{ppm}, \mathrm{Ba}=20 \mathrm{ppm} . \mathrm{Sr}=120 \mathrm{ppm} . \mathrm{Zr}=90 \mathrm{ppm}, \mathrm{Cr}=250 \mathrm{ppm}, \mathrm{K}_{2} \mathrm{O}=0.12 \%, \mathrm{TiO}_{2}=1.50 \%$, $\mathrm{P}_{2} \mathrm{O}_{5}=0.12 \%$ (Pearce 1980), $\mathrm{Ni}=129 \mathrm{ppm}, \mathrm{Co}=45 \mathrm{ppm}$ (Braian et al. 1981) $\mathrm{Cu}=67 \mathrm{ppm}, \mathrm{Zn}=72 \mathrm{ppm}, \mathrm{V}=233 \mathrm{ppm}(\mathrm{Hart}$ et al. 1974). $\mathrm{Pb}=0.9 \mathrm{ppm}$ (Tatsumoto 1978).

Averages for each element: rocks with possible secondary modifications (number underlined) and with extreme compositions (number encircled) are excluded.

Averages for each rock: $\mathrm{Rb}, \mathrm{Sr}, \mathrm{Ba}, \mathrm{Pb}$ and $\mathrm{K}_{2} \mathrm{O}$ are excluded.

3-a. Metadiabase-gabbros.

3-b, Trollheimen volcanics.

Averages are calculated separately for the Na-alkaline rocks (11 rocks) and subalkaline P-group rocks ( 3 rocks). 


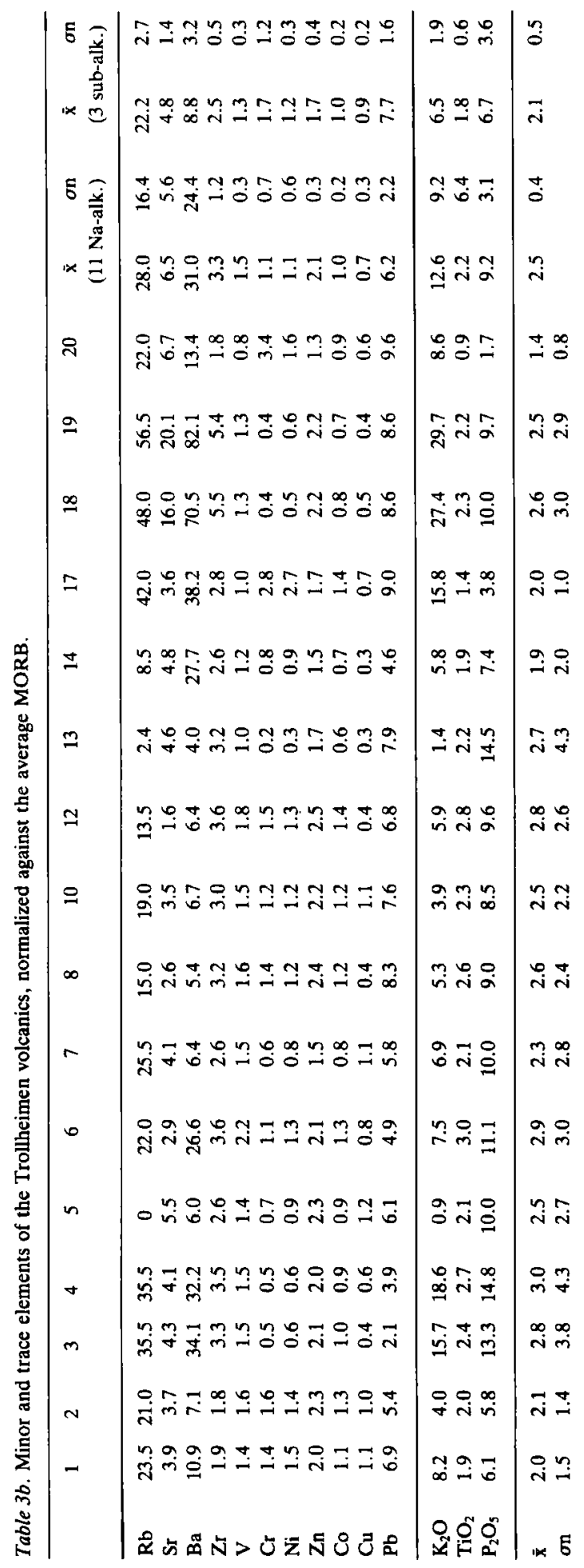

posed oceanic and continental plates must have been an active consuming margin which was responsible for the development of the Svalbard Caledonides.

Oceanic tholeiites have also been reported from both sides of Recherchebreen, south of Bellsund (about $100 \mathrm{~km}$ south of the present area) by Hauser (1982), where the rocks have REE distributions similar to MORB. There, lensoid metadiabase-gabbros with ultrabasic stocks occur in a limestone-rich succession with extrusive volcanics (Turchenko et al. 1983). The calcareous succession is possibly comparable with the CAV formation of the present area. The amphibolites in the north of Hornsund, southern Spitsbergen (about $150 \mathrm{~km}$ south of the present area), also have some tholeiitic rocks, oceanic in terms of $\mathrm{TiO}_{2}-\mathrm{K}_{2} \mathrm{O}-\mathrm{P}_{2} \mathrm{O}_{5}$, together with Na-alkaline and calc-alkaline rocks (Smulikowski 1968). These amphibolites are considered to be in the middle lower Hecla Hoek succession (Birkenmajer 1975). Thus, "oceanic" intrusive rocks occur in older sediments in the southern areas. This means that the supposed approach of oceanic crust may have happened earlier in the south than in the north, i.e., the plate margin was somewhat oblique to the present west coast of Spitsbergen. However, the margin can not have had a very high angle to the west coast, because the main Caledonian structural trend is aligned N-S, subparallel to the coast line, and represents main tectonic transport in an E-W direction.

Some epidote-actinolite greenstones in the high-P metamorphic complex (Vestgötabreen Formation) of Motalafjella, western part of the present area, also show oceanic chemical characteristics in their minor and trace element behaviour (Ohta \& Furnes, unpublished data). These greenstones have abundant lawsonite (Hirajima et al. 1984) and represent a typical low-T, high$P$ metamorphic facies series together with blueschists and eclogites (Ohta 1979; Manby 1979; Ohta et al. 1984). This is an obduction block of oceanic origin, interwoven into the active consuming margin tectonic zone. The occurrence of the oceanic basic rocks in the shallow marine CAV formation reveals a history of the active continental margin before the obduction and the formation of high-P metamorphic rocks.

The metamorphic mineral assemblages give the impression that the Trollheimen volcanics are of lower grade than the metadiabase-gabbros which are definitely of later emplacement. This evidence 
may mean that the two formations had different mutual structural positions during metamorphism. Some inversion structures later than metamorphism have been found in adjacent areas, as in Motalafjella (Ohta et al. 1984) and Prins Karls Forland (Atkinson 1960).

It is difficult to determine metamorphic facies series from the observed mineral assemblages. An occurrence of stilpnomelane may show an intermediate-P facies series for the metadiabase-gabbros, and this conforms with that of the regional metamorphism reported from Prins Karls Forland and Hornsund, western Spitsbergen (Atkinson 1956; Smulikowski 1968; Ohta 1978).

\section{References}

Atkinson. D. J. 1956: The occurrence of chloritoid in the Hecla Hoek Formation of Prince Charles Foreland, Spitsbergen. Geol. Mag. 93, 63-71

Atkinson, D. J. 1960: Caledonian tectonics of Prins Karls Forland. Intern. Geol. Congr. Rep. XXI Sess., Part XIX. 17-27.

Beccaluva, L.. Ohnerstetter, D. \& Ohnerstetter, M. 1979: Geochemical discrimination between ocean-floor and island-arc tholeiites. An application to some ophiolites. Can. J. Earth Sci. 16, 1874-1882

Birkenmajer, K. 1975: Caledonides of Svalbard and plate tectonics. Bull. Geol. Soc. Denmark 24. 1-19

Braian, W., Thompson, G. \& Ludden, J. N. 1981: Compositional variation in normal mid-oceanic ridge basalts from 22-25 N, Mid-Atlantic Ridge. Kane Fracture Zone. J. Geophys. Res. 86, 11815-11836

Garcia, M. O. 1978: Criteria for the identification of ancient volcanic arcs. Earth Sci. Rev. 14, 147-165

Harland, W. B., Horsfield, W. T., Manby, G. M. \& Morris. A. P. 1979: An outline pre-Carboniferous stratigraphy of central western Spitsbergen. Nor. Polarinst. Skr. 167, 119 144.

Hart, S. R. Erlank, A. J. \& Kable, E. J. D. 1974: Sea floor basalt alteration, some chemical and $\mathrm{Sr}$ isotopic effects. Contr. Miner. Petrol. 44, 219-230.

Hauser, E. C. 1982: Tectonic evolution of a segment of the West Spitsbergen Foldbelt in northern Wedel Jarlsberg Land. Ph.D. thesis of Univ. of Wisconsin-Madison.

Hirajima. T. Hiroi. Y. \& Ohta. Y. 1984: Lawsonite and pumpellyite from the Vestgötabreen Formation in Spitsbergen. Nor. Geol. Tidskr. (in print).

Hjelle, A., Ohta. Y. \& Winsnes, T. S. 1979: Hecla Hoek rocks of Oscar II Land and Prins Karls Forland, Svalbard. Nor. Polarinst. Skr. 167. 145-169
Horsfield, W. T. 1972: Glaucophane schists of Caledonian age from Spitsbergen. Geol. Mag. 109(1), 29-36.

Hughes. C. J, 1973: Spilites, keratophyres and igneous spectrum. Geol. Mag. 109, 513-527

Irvine, T. N. \& Barager, W. R. A. 1971: A guide to the chemical classification of the common volcanic rocks. Can. J. Earth Sci. 8. 523-548.

Krasilscikov, A. A. 1979: Stratigraphy and tectonics of the Precambrian of Svalbard. Nor. Polarinst. Skr. 167. 73-88.

Leake. B. E. 1963: Origin of amphibolites from northwest Adirondacks. New York. Geol. Soc. Am. Bull. 74, 11931202.

Manby. G. M. 1978: Aspect of Caledonian metamorphism in central western Svalbard with particular reference to the glaucophane schists of Oscar II Land. Polarforschung 48(1/2), 92-102.

Miyashiro. A. 1974: Volcanic rock series in island arcs and active continental margins. Am. J. Sci. 274, 321-355.

Miyashiro. A. \& Shido, F. 1975: Tholeiitic and calc-alkalic series in relation to the behaviors of Titanium, Vanadium. Chromium. and Nickel. Am. J. Sci. 275. 265-277.

Mohr. P. A. 1960: The geology of Ethiopia. Univ. Coll. Addis Abeba.

Ohta, Y. 1978: Caledonian metamorphism in Svalbard, with some remarks on the basement. Polarforschung 48(1/2), 78-91.

Ohta, Y. 1979: Blue schists from Motalafjella, western Spitsbergen. Nor. Polarinst. Skr. 167, 171-217.

Ohta, Y.. Hiroi, Y. \& Hirajima. T. 1984: Additional evidence of pre-Silurian high-pressure metarıorphic rocks in Spitsbergen. Polar Res. I,n.s. 215-218.

Pearce. J. A. 1975: Basalt geochemistry used to investigate past tectonic environment on Cyprus. Tectonophys. 25. 41-67.

Pearce, J. A. 1980: Geochemical evidence for the genesis and eruptive setting of Lavas from Tethyan ophiolites. Proc. Intern. Ophiolite Symposium. Nicosia. Cyprus.

Pearce, J. A. \& Cann, J. R. 1973: Tectonic setting of basic volcanic rocks determined using trace element analyses. Earth Planet. Sci. Letters 19. 390-300.

Pearce, J. A. \& Flower, M. F. J. 1977: The relative importance of petrogenetic variables in magma genesis at accreting plate margins: a preliminary investigation. $J$. Geol. Soc. London 134. 103-127.

Simonen, A. 1953: Stratigraphy and sedimentation of the Svecofennidic early Archean supracrustal rocks in southwestern Finland. Bull. Comm. Finlande 160, 1-64.

Smulikowski, S. I. 1968: Some petrological and structural observations in the Hecla Hoek succession between Werenskioldbreen and Torellbreen, Vestspitsbergen. Studia Geol. Polonia 21. 97-161.

Tatsumoto, M. 1978: Isotopic composition of lead in oceanic basalt and its implication to mantle evolution. Earth Planet. Sci. Letters 38, 63-87.

Turchenko, S. I., Tebenkov, A. M., Barchatov, D. B. \& Barmatenkov, I. I. 1983: Geological structure and magmatism of the region of Chamberlindalen, West Spitsbergen. pp. 38-48 in: Geology of Spitsbergen, SEVMORGEOLOGIJA, Leningrad (in Russian). 